\title{
Evergreen plants in Roman Britain and beyond: movement, meaning and materiality
}

Article

Accepted Version

Lodwick, L. A. (2017) Evergreen plants in Roman Britain and beyond: movement, meaning and materiality. Britannia, 48. pp. 135-173. ISSN 1753-5352 doi:

https://doi.org/10.1017/S0068113X17000101 Available at http://centaur.reading.ac.uk/68336/

It is advisable to refer to the publisher's version if you intend to cite from the work. See Guidance on citing.

To link to this article DOI: http://dx.doi.org/10.1017/S0068113X17000101

Publisher: Cambridge University Press

Publisher statement: The published article will be available on Cambridge Journals Online.

All outputs in CentAUR are protected by Intellectual Property Rights law, including copyright law. Copyright and IPR is retained by the creators or other copyright holders. Terms and conditions for use of this material are defined in the End User Agreement. 


\section{www.reading.ac.uk/centaur}

\section{CentAUR}

Central Archive at the University of Reading

Reading's research outputs online 


\section{Evergreen Plants in Roman Britain and Beyond: Movement, Meaning and Materiality}

Article

Accepted Version

Note: This is a post-print of an article accepted for publication in Britannia 


\title{
Evergreen Plants in Roman Britain and Beyond: Movement, Meaning and Materiality
}

By Lisa A. Lodwick

\begin{abstract}
In tandem with the large-scale translocation of food plants in the Roman world, ornamental evergreen plants and plant items were also introduced to new areas for ritual and ornamental purposes. The extent to which these new plants, primarily box and stone-pine, were grown in Britain has yet to be established. This paper presents a synthesis of archaeobotanical records of box, stone-pine and norway spruce in Roman Britain, highlighting chronological and spatial patterns. Archaeobotanical evidence is used alongside material culture to evaluate the movement of these plants and plant items into Roman Britain, their meaning and materiality in the context of human-plant relations in ornamental gardens and ritual activities. Archaeobotanical evidence for ornamental evergreen plants elsewhere in the Roman world is presented.
\end{abstract}

Keywords: box; stone-pine; Roman Britain; Roman gardens; plant materiality; archaeobotany

\section{INTRODUCTION}

The introduction of a wide range of new plants in the Roman period marked a major change in the Holocene flora of Britain. While the presence of a diverse range of horticultural crops, including fruits, nuts, pulses, vegetables and flavourings, has received much attention, another category of plants, ornamental evergreen shrubs and trees, was also introduced. ${ }^{1}$ Archaeobotanical evidence for the presence of box (Buxus sempervirens L.) and stone-pine (Pinus pinea L.) (FIG. 1) in Roman Britain has been known of for over 100 years. $^{2}$ However, the wealth of new archaeobotanical data produced following the upsurge in developer-funded archaeology has yet to be used to develop a more nuanced understanding of the chronological and social patterns of these new plants. ${ }^{3}$ Independent of these developments, several scholars have approached the translocation of plants in the Mediterranean, such as plane, citruses and cherry, through the lenses of elite behaviour, cultural change and environmental concerns, with particular focus on plants in private and public gardens, albeit largely drawing on a 
range of written evidence. ${ }^{4}$ Globalisation, the intensification of connectivity, has previously been used to study the movement of food plants, but the translocation of ornamental plants also reflects the spread of material culture throughout the Roman world. ${ }^{5}$ The limited exploration of the archaeobotanical evidence for introduced plants in Roman gardens is countered here by a focus on the province of Britannia which has an exceptional record of plant remains. The presence of introduced ornamental evergreen plants in Roman Britain has significance both for understanding the ecological impacts of Rome on its empire and for exploring the changing relationships between humans and plants. ${ }^{6}$ Recent studies in the fields of anthropology, human geography and philosophy have highlighted the ways in which plants can affect or 'act on' humans, following in the wake of the 'the material turn' and 'the animal turn' ${ }^{7}$ This broad and vibrant field of human-plant studies is beginning to impact upon the field of archaeology, with the focus thus far placed on how plants can act upon humans in relation to the activities of farming and ritual, with no consideration yet given to ornamental plants. ${ }^{8}$
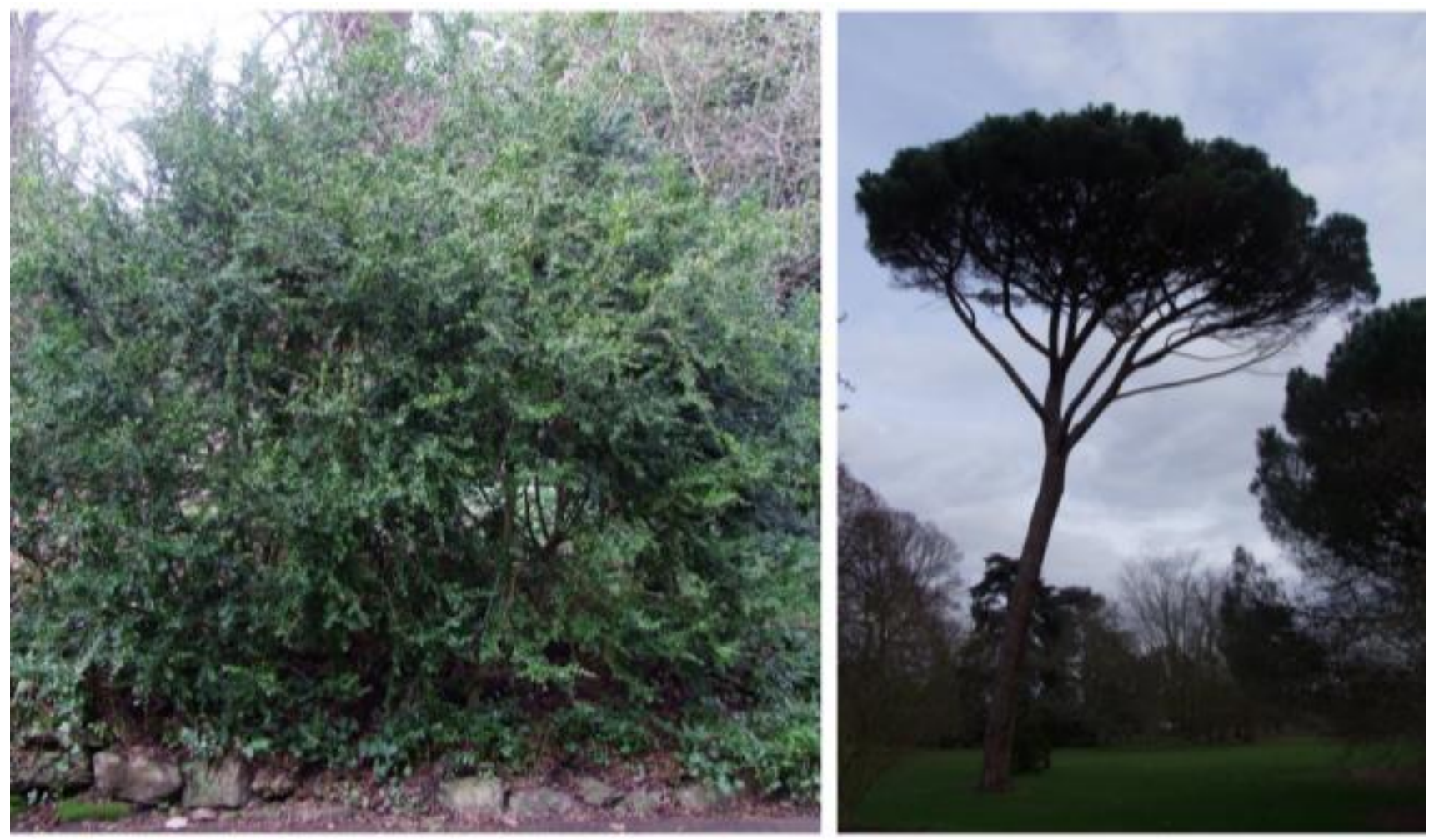

FIG 1. Box (Buxus sempervirens) and stone-pine (Pinus pinea) trees growing at Kew Gardens, London, UK. 
A reassessment of ornamental plants is crucial for understanding human-plant relationships in the past, but also in the present. Box is currently classed as a native plant in Britain, although its native status continues to be questioned in north-west Europe. ${ }^{9}$ However, box is rare and is currently suffering from box blight and the box tree moth. ${ }^{10}$ The status of box as a native or alien plant contributes to the extent of conservation and protection the plant receives today. This paper draws on the rich archaeobotanical dataset from the province of Britannia to identify the chronological, spatial and social distribution of box, stone-pine and norway spruce in Roman Britain, before assessing evidence for the movement of these plants to Britain and material culture and literary evidence for their meaning. The idea of plant materiality, that is recognising the agency of plants in human-plant relationships, is advanced through a consideration of the visual appearance, smell, physicality and temporality of introduced evergreen plants and plant items.

\section{EVERGREEN PLANTS IN THE ARCHAEOLOGICAL RECORD}

\section{Preservation}

The recovery of evidence for the presence of ornamental plants at archaeological sites has long been recognised as a challenging field. In certain areas, such as Campania and Tunisia, the techniques of 'garden archaeology' have been utilised, most prolifically by Jashemski, to recognise planting holes, water systems and garden layouts. ${ }^{11}$ In Britain, garden layouts have been recorded at a few sites, such as Bancroft, Fishbourne and Frocester villas, yet evidence for planting holes is rarely found and, instead, archaeobotanical evidence must be relied upon to provide information about garden composition. ${ }^{12}$ The remains of evergreen plants are found through two modes of preservation in Britain. Charring, the partial combustion of plant remains in a reducing atmosphere, is unlikely to produce evidence for ornamental plants as these do not usually come into contact with fire. However, there are high numbers of charred stone-pine cones and nuts due to their occurrence in ritualised deposits. Waterlogging, the preservation of plant remains in permanently waterlogged anoxic sediments, either below the water table in pits or wells, or waterlogged in highly organic surface deposits, often preserves delicate plant remains, such as box leaves. However, waterlogged assemblages often contain plant remains of mixed origin, hindering their interpretation. ${ }^{13}$ In addition, the distribution of sites with waterlogged sediments is biased towards gravel terraces and urban 
settlements. Box leaves recovered from inhumation burials are likely to have derived from a type of metal oxide mineralisation, yet these sites are all antiquarian finds and the precise form of preservation cannot be established.

The systematic recovery of plant remains from archaeological sites relies upon bulk sampling, not introduced on a wide scale until the late 1970s. ${ }^{14}$ However, due to their relatively large size, box leaves and stone-pine cones were both collected by hand throughout the earlier twentieth century. While this produced a record of these plants, any smaller plant remains would not have been recovered, hence their relative distribution within a site and through time can therefore not be examined. A further recovery bias affecting where these plants have been recorded is the concentration of post Planning Policy Guidance 16 archaeobotanical work in the south-east of Britain, as well as at major modern settlements and route ways. ${ }^{15}$ Archaeobotanical data can provide much more precise evidence for the types of plants growing than garden archaeology, yet these biases of preservation and recovery must be kept in mind when interpreting patterns in the data.

\section{Previous Work on Imported Evergreen Plants}

Antiquarian excavations from the mid-nineteenth century onwards produced evidence for the presence of introduced evergreen plants in Roman Britain. The plant remains were sent to botanists for identification, as with the identification of box leaves from an inhumation burial at Chesterford, Essex identified by Professor Henslow at the University of Cambridge. Likewise, box leaves from an inhumation at Cann were identified by the geologist and palaeobotanist Clement Reid. Even in this early work, the archaeobotanical evidence was related to the status of box as an introduced plant. To quote from Reid 'The box has been considered a doubtful native of Britain, but now we have it at two localities associated with Roman remains'. ${ }^{16}$ Similarly, an object described as a 'fir cone' was recovered from waterlogged sediments at the New Royal Exchange site, London in the 1840 s ${ }^{17}$ which in hindsight seems likely to have been a stone-pine cone. No significance was attached to the find and it was not until the mid-twentieth century, following the recovery of charred stone-pine remains from several religious sites, that their role in ritual activities was recognised. ${ }^{18}$

The importance of these records from a botanical perspective was highlighted by Godwin in his seminal review of the flora of the British Isles. ${ }^{19}$ In his synthesis of Roman agriculture, Applebaum 
did not include stone-pine, but instead listed deciduous trees as introductions to Roman Britain such as the 'Spanish chestnut, horse chestnut, sycamore, walnut, holm-oak and possibly the Spanish laurel', ${ }^{20}$ all of which are now considered as doubtful introductions. Box was considered to be 'not a Roman introduction, but may have been encouraged for this [funerary] and other uses' ${ }^{21}$ By the late 1970s, it had been firmly established that a range of exotic plants was introduced to Roman Britain. ${ }^{22}$ The proliferation of rescue excavation produced further archaeobotanical finds of imported evergreen plants, many of which have remained unpublished in grey literature. Key examples are from villas at Stanwick, Northamptonshire, and Rectory Farm, Godmanchester. ${ }^{23}$ Nevertheless the growing archaeobotanical evidence was incorporated within several key syntheses of Roman gardens in Britain. Cunliffe considered the introduction of new flora, including stone-pine and box, as a product of 'intensive Romanisation', ${ }^{24}$ and concentrated instead on the architectural evidence for Roman gardens. A decade later, Zeepvat again focused on the evidence for garden layout at the villas at Fishbourne, Frocester and Bancroft, briefly noting that 'the ubiquitous box was used as a hedging plant throughout the western Empire'. ${ }^{25}$ While two key syntheses have briefly summarised the evidence for introduced evergreens alongside the main subject matter of food plants in Roman Britain, ${ }^{26}$ the prevailing field of garden archaeology has subsumed the study of introduced plants within the locales of the villa and peristyle garden. ${ }^{27}$

\section{Data Collection and Interpretation}

In order to produce a new understanding of the introduction and use of evergreen plants in Roman Britain, archaeobotanical reports have been reviewed from all Roman rural settlement sites, utilising the published and grey literature synthesised in the Roman Rural Settlement Project database,${ }^{28}$ and published data from urban and military sites. The presence of box leaves, stone-pine cones and nutshells, as well as other introduced evergreen plants has been recorded on a 'record basis', i.e. presence per major site phase. ${ }^{29}$ Site classification follows that of the Roman Rural Settlement Project and period classification is as follows: activity from c. A.D. 43 - end first century and into the second century (Early Roman); second and third centuries (Middle Roman); fourth century (Late Roman).

The focus in this paper is on plant remains which may have derived from trees and shrubs growing in Roman Britain. Artefactual evidence for objects made from boxwood and Abies alba L. 
(silver fir), such as combs and writing tablets, ${ }^{30}$ is not included, as their portability is considered to limit their ability to provide useful evidence for the presence of introduced evergreen plants. Macrofossils (seeds, leaves, cones), rather than pollen evidence, are the focus of this study as they are considered to provide more direct evidence for the presence of evergreen plants or plant items. Charcoal records have also been retrieved from the archaeobotanical computer database and by consulting specialists. ${ }^{31}$ A list of archaeobotanical data and references is provided in Appendix Tables 1 and 2, while pollen studies are referred to where available.

In order to establish whether plant remains represent in-situ plants or portable plant-derived items, attention has been paid to the context and condition of plant remains. Where possible, taphonomic evidence for the plant remains themselves (charring and fragmentation) ${ }^{32}$ and the context in which the plant remains were recorded has been noted. ${ }^{33}$ The interpretation of the records draws on two areas of study. First, literary, artistic and archaeobotanical evidence from the Roman world has been used to evaluate to what extent the meaning of evergreen plants in Roman Britain can be established. Second, ethnographic studies are drawn upon within cultural geography which have highlighted how plants affect people through characteristics such as colour, structure and ecological temporality ${ }^{34}$ - considerations which closely correspond with multi-sensory approaches within classical archaeology. ${ }^{35}$

\section{EVERGREEN PLANTS IN ROMAN BRITAIN: RESULTS}

\section{Box - Buxus sempervirens}

Box is an evergreen shrub or small tree, certainly native to southern Europe, northern Africa and western Asia. ${ }^{36}$ In Britain today, it is found in woods and scrub on calcareous limestone escarpments, restricted to west Kent, Surrey, Berkshire, Buckinghamshire and west Gloucestershire. ${ }^{37}$ Various ancient authors, including Pliny the Younger, describe the use of box in Roman villa gardens, particularly for topiary. ${ }^{38}$ Box is also depicted in several fresco scenes, including at Livia's villa at Prima Porta, Rome. ${ }^{39}$ By contrast, evidence for the use of box in Roman Britain is almost entirely based on archaeobotanical evidence. Macrofossil plant remains of box have been recovered from 31 sites in Roman Britain, 24 of which are waterlogged occurrences. Exceptions are a charred leaflet from Stonea, Cambridgeshire, ${ }^{40}$ and charcoal from Frocester Villa, Gloucester, and Westhawk Farm, Kent, ${ }^{41}$ and 
the likely metal oxide mineralised box leaves recovered from four burials at Bartlow Hills, Cann, Chesterford and Roden Down. The distribution of box by site type (FIG. 2) shows that evidence for box has most commonly been recovered from major towns (14 records), followed by burials and villas (five records each), four farmsteads and two religious sites (Bath and Marcham). However, it is also worth noting that the major towns are only London, Silchester and York, all sites which contain many archaeological deposits with waterlogged preservation and a long history of archaeobotanical investigation. $^{42}$

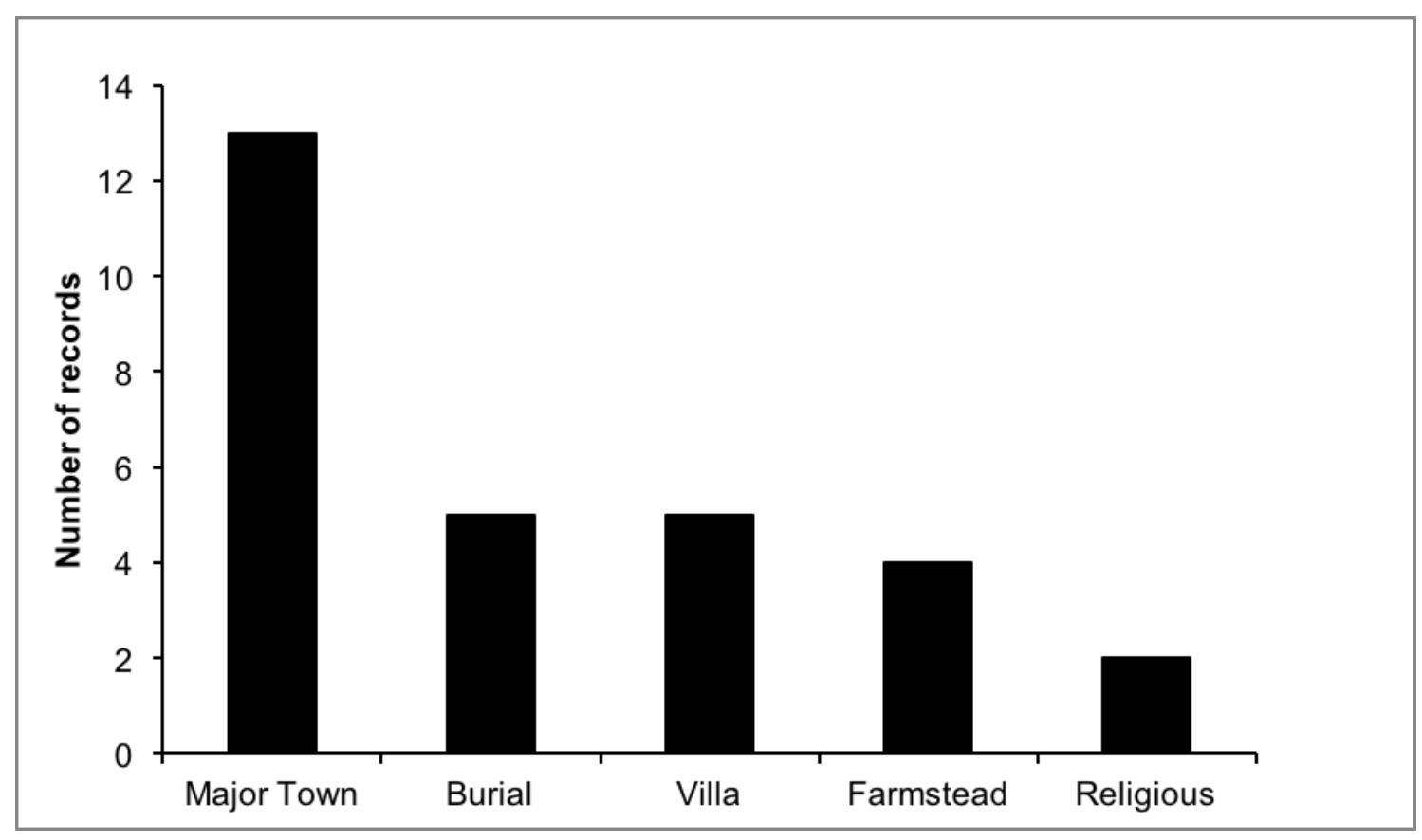

FIG. 2. Distribution of waterlogged macrofossil finds of box by site type.

The burials are located in Dorset, Berkshire, Cambridgeshire and Essex and stretch from the Early to the Late Roman period. At the Bartlow Hills cemetery, box leaves and branches were found adhering to the base of a cremation urn and date to the late first/early second century. ${ }^{43}$ Two of these burials are child inhumations. At Scole, Norfolk, a sample from the chest area of an early- to midsecond-century inhumation contained box leaves and many fruits of Deadly Nightshade (Atropa belladonna L.). ${ }^{44}$ These were considered to have been intentionally placed as a wreath, but no data were presented in the publication against which to evaluate this claim. An undated burial of a child in a lead coffin at Cann, Dorset, contained a large number of box leaves and short sprigs around the head. 
Again, these were interpreted as a wreath, but no detailed record was made. ${ }^{45} \mathrm{~A}$ further example of a lead-lined coffin burial was that of an elderly (50+) woman from Roden Down, Berkshire, where box leaves and young stems were recorded as lining the base of a coffin and around the head and legs. The burial was dated to after A.D. $364 .{ }^{46}$

The spatial distribution of box is largely focused in central-southern Roman Britain, a pattern heavily affected by the distribution of sites with waterlogged preservation in the major river valleys of the Thames, Nene and Ouse (FIG. 3). The rural farmsteads and roadside settlements where box has been recovered are located in both the Upper Thames valley, Ouse valley, Somerset and Suffolk, while the villas where box has been identified stretch from Godmanchester in Cambridgeshire to Winterton in Lincolnshire. The chronological distribution of box (FIG. 4) shows that the presence of box leaves within settlements was largely confined to the second century onwards. The only Early Roman records are that of the box leaves at the Bartlow Hills cremation burial and at the Drapers Garden site in London. Here, several intact box leaves were recovered from a ditch dating to the later first century. ${ }^{47}$ At the New Royals Baths site in the south-west of Bath, box twigs were recovered from a ditch which was backfilled with late first- and early second-century ceramics. ${ }^{48}$ 


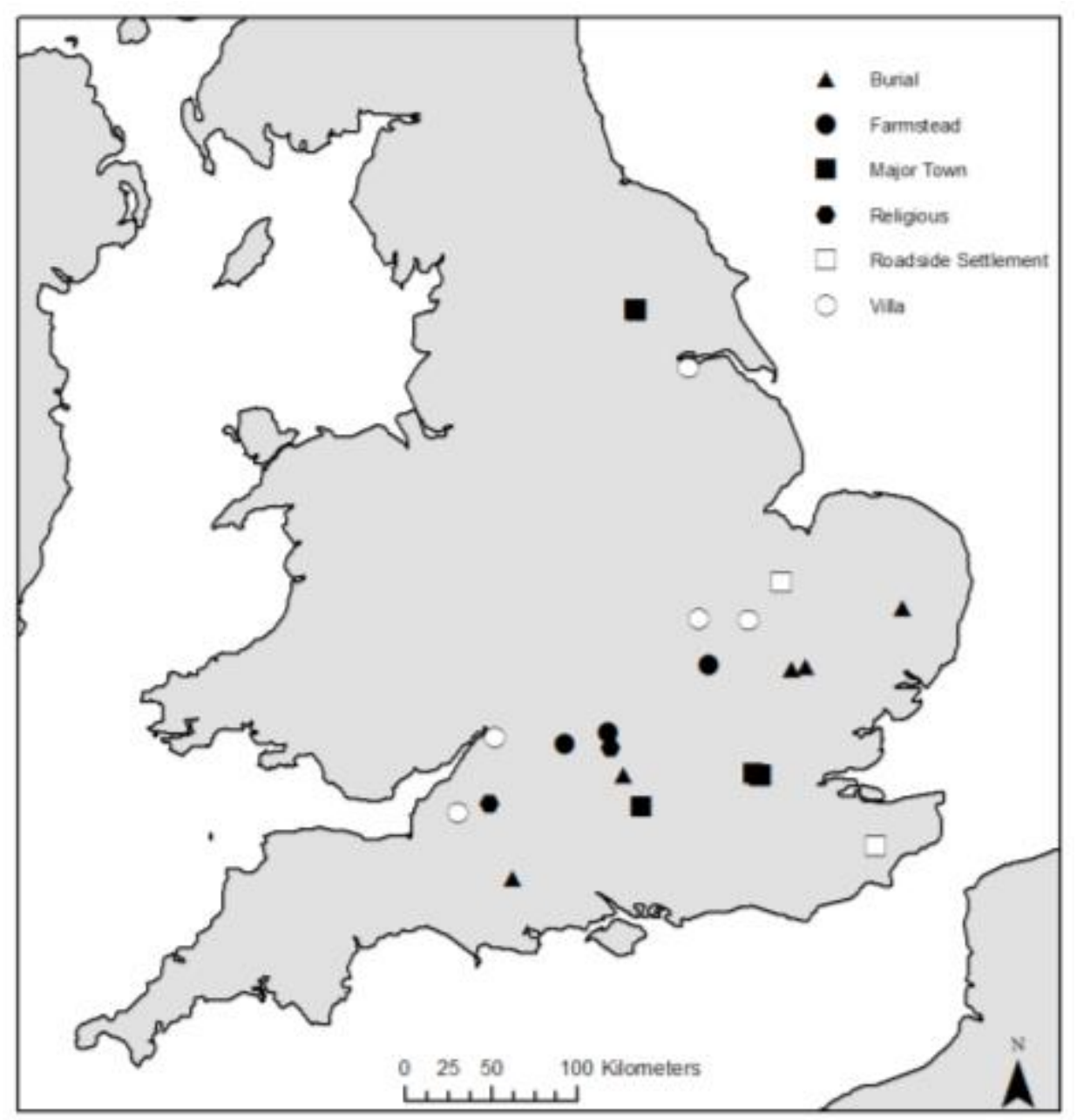

FIG. 3. Spatial distribution of macrofossil finds of box.

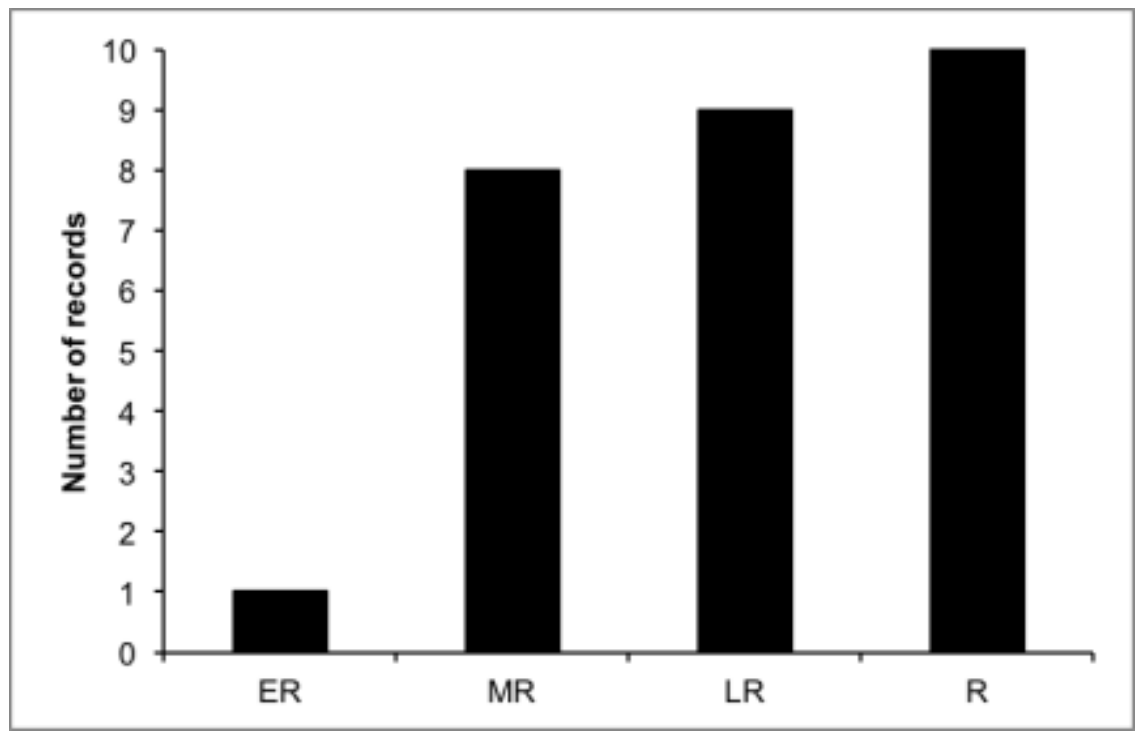

FIG. 4. Chronological distribution of macrofossil finds of box. 
Of the eight Middle Roman records, virtually all derive from the major towns of London, Silchester and York, as well as the religious centre at Bath. Box leaves have not been recovered from any other major towns. This pattern is largely due to preservation and sampling, as very few or no waterlogged samples have been analysed from other major towns such as Cirencester, Lincoln, Leicester or Colchester. Evidence for Middle Roman box has also been recovered from the eastern area of Roman Britain, from a child's burial at Scole and a charred box leaflet from the roadside settlement at Stonea. While there is no marked rise in the number of records in the Late Roman period (nine), box leaves have been found at a wider range of sites, including the villas at Frocester, Godmanchester and Stanwick, as well as rural farmsteads at Marsh Leys, Kempston and Farmoor. The examples dated only to the Roman period derive from antiquarian investigations of burials, villas and towns, as well as unpublished grey literature. The chronological pattern presented here is based on the number of sites per period, with the potential that the total number of sites investigated per period could differ. However, the same pattern was identified by the national review of Van der Veen et al., with an increase in the frequency of box within all waterlogged records from 1 per cent in the Early Roman period to 13 per cent in the Late Roman period. ${ }^{49}$

Establishing a more precise understanding of the use of box at these settlements is difficult. Many box leaves do not have precise sampling information, either because they were hand-collected during excavation, as at 15-35 Copthall Avenue, London, or because no sampling information was included at publication. An inherent limitation of studying waterlogged plant remains is that waterlogged assemblages usually contain material from a diverse range of sources, making it difficult to identify the source of one component of a sample. Box leaves included in this category are the leaves from the waterfront infill deposits at 12 Arthur St, London, and leaves from various levelling and accumulation deposits at General Accident Site/Tanner Row in York. It is conceivable that these box leaves may have derived from dumped rubbish originating from either the distant or immediate area. In some cases, a local source can be suggested based on the consistent presence of box leaves in an area, as with six out of seven of the well fills at Skeldergate, York. Exemplary sites where the spatial association of box remains can be established are at 1 Poultry, in the western suburb of Roman London. Here box leaves and stems, and cf. Pinaceae (conifer) leaves, were found interleaved in silting over a later third-century gravel road surface of the main west-east street through the town, close to a high- 
status building, providing a strong indication of a nearby box shrub. Similarly, at Silchester Insula IX, a fragment of box leaf was recovered from the backfill of a well in the eastern area, adjacent to the main north-south street. Aside from the archaeobotanical evidence, indirect evidence for the presence of box plants comes from planting trenches at Fishbourne. Sampling for plant macrofossils and pollen was unsuccessful. However, distinctive bedding trenches were cut into the gravel and clay soil along the pathways of the formal garden of the Flavian palace. These were filled with loamy soil, strongly indicating the planting of box, which naturally grows in calcareous soils. ${ }^{50}$

Archaeological box leaves are typically described as 'clippings', implying that these are stems and leaves of box clipped off from a box shrub as it was shaped for topiary. Indeed, the box leaves recovered from a villa at Wiesweiler, the Rhineland, have been described as having straight cut edges, which was taken as evidence that these shrubs had been trimmed for topiary. ${ }^{51}$ Unfortunately, separating between a box leaf which has been cut by shears and one which has fragmented during or post-deposition is not clear, as the condition of box leaves is rarely noted in archaeobotanical reports. At Winterton villa, no report is available, but a photograph of the box remains clearly shows $c .4 \mathrm{~cm}$ lengths of box stem with attached leaves. ${ }^{52}$ In contrast, at Skeldergate, York, detached leaves without stems were interpreted as dead leaves, rather than clippings from topiary. ${ }^{53}$ Other potential ways to identify the management of box shrubs would be the presence of pruning scars on stems, indicating that the shrub had been previously pruned. Clusters of flowers are situated in the leaf axils of box plants, which flower in April and May. ${ }^{54}$ At two sites box fruits have been recovered: Claydon Pike and Farmoor, both rural settlements in the Upper Thames valley. Although the river gravels do not represent the natural habitat of box shrubs, perhaps these plants indicate planted hedges, not closely trimmed into topiary bushes and hence retaining their flowers until the fruits developed. FIG. 5 shows the records of box classified by the parts recorded. In the majority of records (13), only leaves are present, not providing any evidence for topiary. Sprigs were present at five sites, but the majority of these are burials. At Chew Park, waterlogged, worked wood, inner bark and leaves of box were recovered from a well, indicating that box was being used for woodworking.

This review of the archaeobotanical records of box leaves has demonstrated that there are chronological and spatial trends in the presence of box plants. They were more common in towns than the countryside, and were more common over time. 


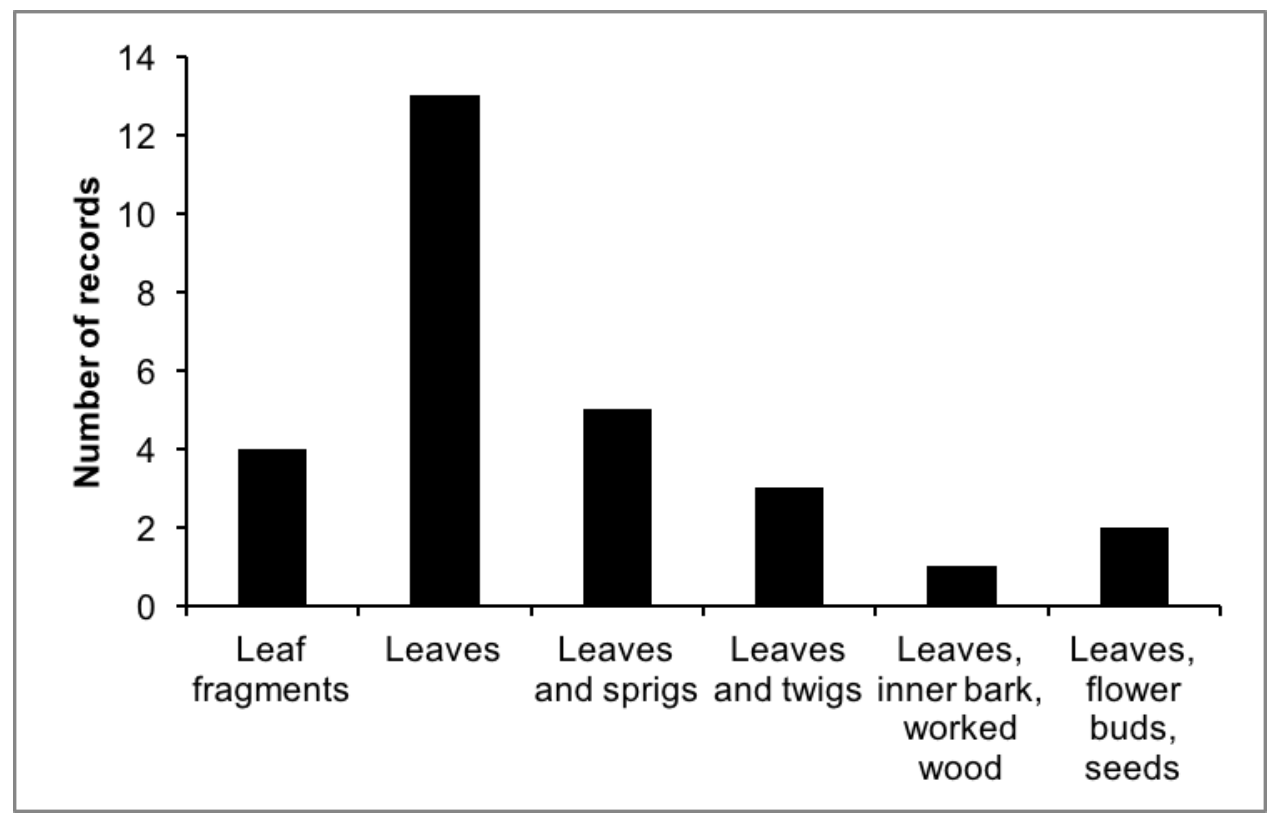

FIG. 5. Distribution of waterlogged box finds by part identified, where specified.

\section{Stone-Pine - Pinus pinea}

The second imported evergreen plant recorded in Roman Britain is the pine tree, variously known as the Mediterranean, stone or umbrella pine. Stone-pine is an evergreen plant native to wide areas of the Mediterranean. ${ }^{55} \mathrm{~A}$ wealth of material culture evidence from the Roman world shows the significance of the pine cone symbol, from hair pins, to mortuary tombstones, to fountains. ${ }^{56}$ Furthermore, artistic evidence shows the inclusion of stone-pine alongside other ornamental garden plants in garden frescoes. ${ }^{57}$ Pine nuts, harvested from wild forests, were a common food item in Roman cuisine, featuring in the recipes of Apicius, and the nutshells occur in refuse deposits where sampled. ${ }^{58}$ Ritual offerings including stone-pine cones and nuts are common occurrences within public temples, household offerings and at funerary sites. ${ }^{59}$ Indeed, recognition of the role of pine cones in ritual offerings is long established. ${ }^{60}$ However, the extent to which stone-pine trees were cultivated beyond the Mediterranean, and their interactions with humans beyond explicit ritualised occasions, has not been investigated. Stone-pine cones and nutshell are present in 41 records from Roman Britain, of which 23 are waterlogged, 15 charred and three unspecified (FIG. 6). 


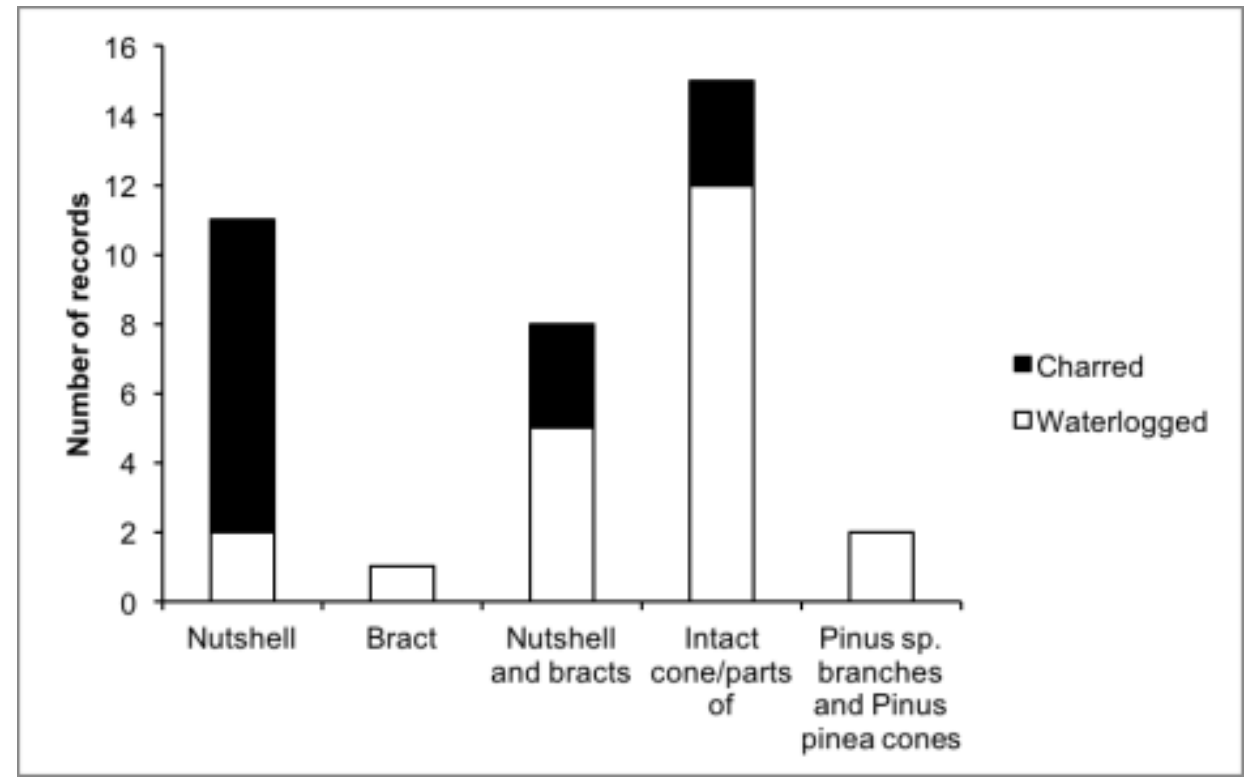

FIG. 6. Distribution of stone-pine finds by part identified and preservation, where specified.

The majority of these stone-pine finds derive from the major towns (16), while many of the other site categories are located within major towns, such as the Triangular Temple at Verulamium, the Romano-Celtic Temple complex at Lower Brook Street, Winchester, and the funerary site at Finsbury Circus, London. Smaller numbers of stone-pine cone remains have been recovered from villas, religious, funerary and military sites (FIG. 7). The five funerary sites from which stone-pine remains have been recovered are all cremation cemeteries associated with a range of communities, from urban (Watling Street), to rural (Horcott Quarry, Mucking) and military (Doncaster). Rural finds of stone-pine consist of charred nutshell identified from roadside settlements and other rural sites in Essex, Hampshire and Kent, and whole cones from farmsteads at Chew Valley and Claydon Pike, as well as at several villas (Bancroft, Clatterford, Great Holts Farm, Lullingstone). Considering the profusion of excavated rural settlements in Roman Britain, there appears to be a genuine low presence of stone-pine in rural Britain beyond these villas and several farmsteads. 


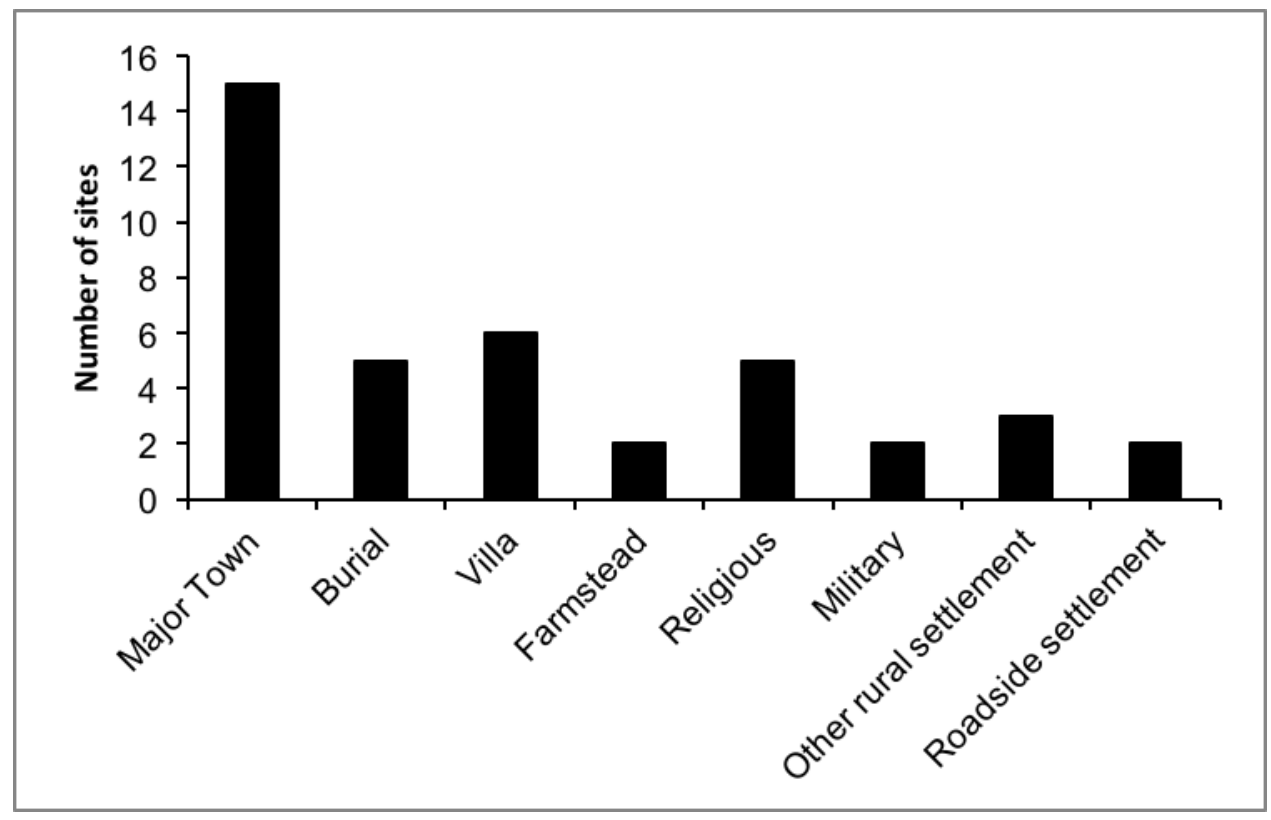

FIG 7. Distribution of macrofossil finds of stone-pine by site type.

The chronological distribution of stone-pine records (FIG. 8) show that they are largely concentrated in the Middle Roman period, albeit with more Early Roman records than box. This pattern was also identified in the previous national review, which recorded Pinus pinea in 1.5 per cent of Early Roman, 3.5 per cent of Middle Roman and 2 per cent of Late Roman charred records. ${ }^{61}$ Records from the second half of the first century are concentrated in the south-east of Britain, from the military fort at Alchester, occupation in London and Colchester, and the shrine site at Westhawk Farm, Kent. Middle Roman records are far more widespread, occurring also at rural farmsteads and villas, as well as in many records from towns and more widespread funerary and religious sites. The Late Roman records derive from three rural settlements: Fullerton villa, Newmans' End field system and Chew Park farmstead, and sites in London. Of the broadly dated sites, some are more likely to derive from the Later Roman period (Bancroft and Low Ham villa). Stone-pine finds are more widely distributed than those of box (FIG. 9), as the majority are charred records found outside of areas with waterlogged preservation. There is a particular focus of records in London and surrounding settlements with numerous sites located in Kent. 


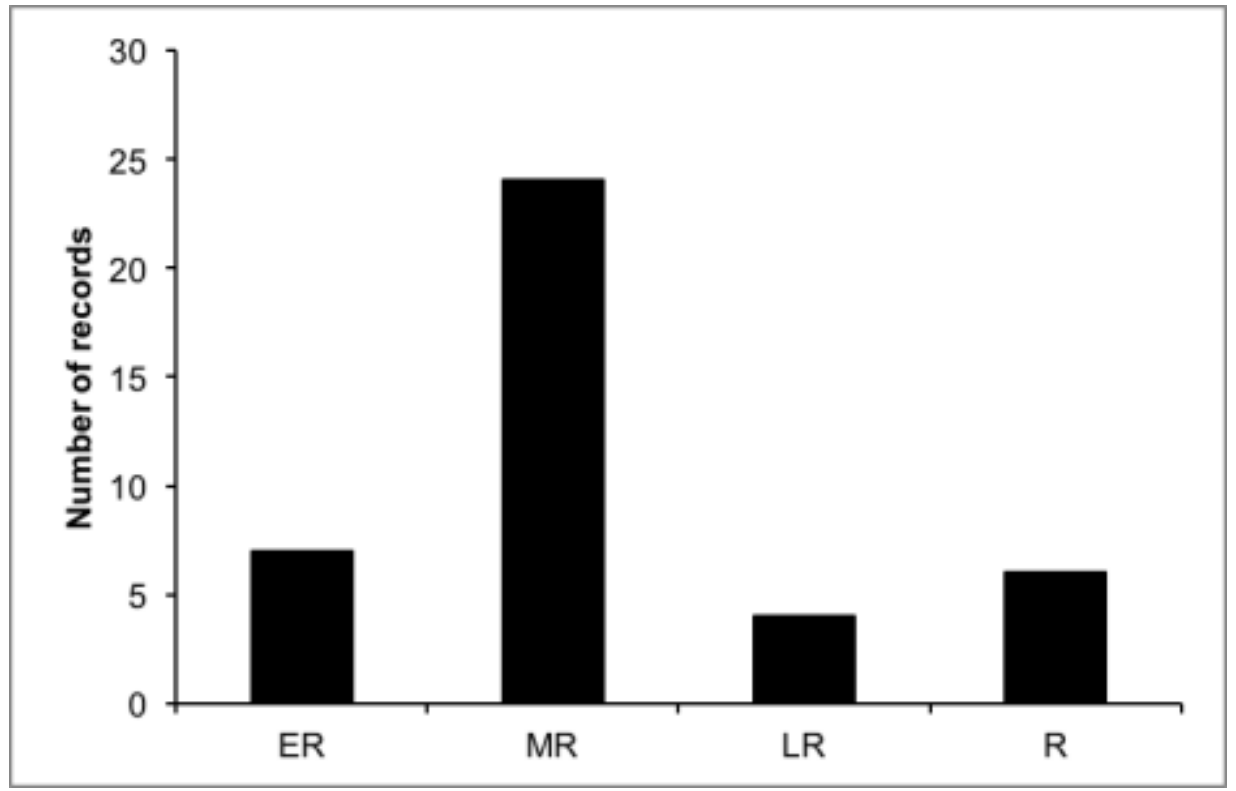

FIG. 8. Chronological distribution of macrofossil finds of stone-pine.

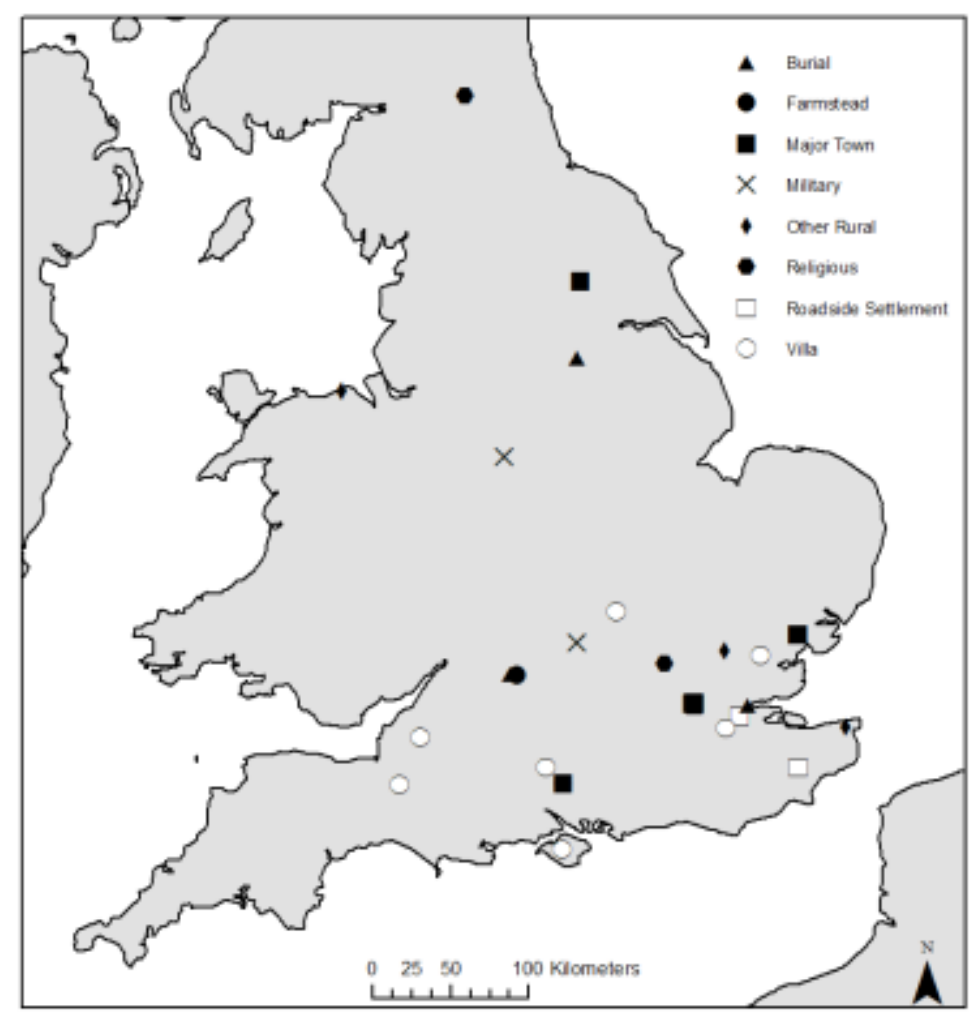

FIG. 9. Spatial distribution of macrofossil finds of stone-pine.

This review of the range of sites from which pine cones remains have been recovered shows that archaeobotanical finds of stone-pine originate from a diverse range of activities. Previous work has shown that it is not possible to identify ritualised deposition of plant items based on archaeobotanical evidence alone, as there is no correlation between the density of stone-pine remains 
and sites with clear sacred uses. ${ }^{62}$ Furthermore, taphonomic details which could provide insights into the depositional pathways of pine cone remains, such as fragmentation rate, and full quantification of nut shell and bracts, were rarely included in the reports reviewed here. Regardless, a broad consideration of site, artefacts and archaeobotanical remains, groups sites into four main categories. The first includes those where stone-pine cones or nuts were clearly associated with funerary activity and are recovered from the fill of cremation burials. In particular, pine cone remains were found alongside distinctive assemblages of material culture at two sites. ${ }^{63}$ At Waterdale, Doncaster, finds from a cremation cemetery associated with a nearby late first-century fort produced pine nut, olive, date, fig, grape and lentil, alongside ceramic oil lamps, glass unguentaria and amphorae. A late secondcentury cremation at Mucking, Essex, included an epula deposit of the remains of a ritual meal, containing pine nuts, date, hazelnuts and around ten place settings, each including a ceramic oil lamp, coin, tazza, beaker and platter. The second category of sites are those where stone-pine remains were recovered from within an area of sacred architecture, either as an in-situ offering (Verulamium triangular temple) or redeposited in a nearby pit or pool (Westhawk Farm, Springhead). At the third category of sites, stone-pine cones have been recovered from features which are plausible locations of structured deposition (waterholes, wells, ditches). Examples are Clatterford villa, where a ditch to the south of the villa building produced a cone, and Claydon Pike, where a cone was recovered some distance from the main settlement area in a waterhole. Finally, at seven sites, pine nutshell fragments have been recovered from typical occupation deposits, such as hearths and refuse deposits. Examples are low-density finds of charred fragmented nutshell at Newman's End, Essex, and Springhead Roman town. Additionally, branches identified as Pinus sp. and several stone-pine cones were recovered from a ditch outside the London amphitheatre. Regardless of which category a stone-pine record may fit into, stone-pine cones were clearly being consumed in Roman Britain as food or ritualised offerings. The more interesting question, whether they were also growing in Britain, will be addressed in the next section.

\section{Norway Spruce - Picea abies}

Norway spruce, the tree most commonly used as a Christmas tree in Britain today, is the third introduced evergreen plant to be recorded in Roman Britain. Picea abies grew in central and north-east 
Europe during the Roman period and, as with stone-pine and box, the use of norway spruce in the Roman world ranged from providing timber for buildings and ships, to featuring alongside box in painted garden scenes. ${ }^{64}$ Plant remains have been found at only four sites in Britain. At Rectory Field, on the north-eastern outskirts of Roman Godmanchester, an extensive farmstead and later villa settlement produced substantial evidence for an ornamental garden containing a range of introduced trees. Preliminary results include the identification of wood, leaves, twigs, cones and seeds of P. abies from the waterlogged sediments of several ponds. Wood identified from the site included yew, alder and hazel, while box leaves were also recovered; $P$. abies pollen was identified from other features. ${ }^{65}$ Murphy has also stated that Pinaceae cones identified from the roadside settlement at Stonea Grange, Cambridgeshire, originally identified as Pinus sylvestris, the native tree scot's pine, were actually $P$. abies. ${ }^{66}$ A possible record of needles originates from the London 1 Poultry excavations, where the same sample which contained laminated box leaves also produced cf. Pinaceae leaves. ${ }^{67}$ Tentative evidence also comes from south-east England for the presence of P. abies, based on palynological records. At the site of Westhawk Farm, where charred stone-pine nutshells were recorded from the central pit of a shrine, $P$. abies pollen was recovered consistently from the upper $100 \mathrm{~cm}$ of a sample from a waterhole near to the shrine and was interpreted as originating from a nearby P. abies tree. ${ }^{68}$ Indeed, Wiltshire has stated that Picea was growing more widely in south-east Britain in the Roman period. Picea pollen was recovered from the fills of a ditch dated to 100/50 B.C.-A.D. 50 from Zionhill's Copse, Hampshire. ${ }^{69}$ Picea pollen was also recorded from various pollen cores from the Jubilee Line programme of excavation and coring in London. However, all occurrences of Picea are from undated cores or dated to the Iron Age. While the preservation of the Picea pollen was consistent with secure Holocene records, many of the deposits are fluvial with evidence for reworking, while there is a strong possibility of long-distance fluvial/marine transport of exotic pollen. ${ }^{70}$

\section{Other Imported Ornamental Plants}

While not specifically evergreen plants, single records of two Roman ornamental trees are significant finds and require mention here. Archaeobotanical evidence indicates that the plane tree was introduced to southern Italy in the Roman period, according to Pliny, to provide shade. Plane also had a strong connection with philosophy through its association with the Platonic Academy and it featured 
commonly in public and private parks. For instance, it has been suggested that plane trees lined the portico gardens of Pompey in Rome. ${ }^{71}$ A single seed of Platanus orientalis, oriental plane, was recovered from a second-century pit alongside various food remains (including celery, coriander, cherry, plum), on the site of a high-status building on the corner of Akeman Street and the via Devana in the small town of Cambridge. ${ }^{72}$ However, no archaeobotanical report was provided and this record must be treated with caution.

A single fragment of laburnum wood charcoal (cf. Laburnum sp.) was identified from an Early Roman grave at Springhead, Kent. This plant has pendent racemes or long lengths of yellow flowers and, alongside a fragment of the flowering plant traveller's joy (Clematis vitalba), may represent the purposeful selection of flowering plants for a funerary associated fire. ${ }^{73}$ Beyond these ornamental taxa, the frequency with which archaeobotanical evidence for fruit trees such as plum, cherry and apple/pear are encountered in Roman Britain has led to suggestions that these trees were cultivated by the Middle Roman period. ${ }^{74}$

\section{DISCUSSION}

\section{Import or Cultivation?}

This review of archaeobotanical records for box, stone-pine and norway spruce in Roman Britain has demonstrated the presence of items originating from these trees, especially in Middle-Late Romanperiod London and other sites in the south-east of Britain. However, many of these items could potentially have derived from trade in plant parts rather than in-situ trees. For instance, fallow deer are represented by antler and foot bones in the Roman period of north-western Europe, suggesting the curation of these items as artefacts. ${ }^{75}$ These two scenarios, of cultivation or import, have substantially different implications for understanding the effect of plants on people in Roman Britain.

In the case of box, some archaeobotanical examples do provide evidence of the use of box leaves and sprigs as items of material culture in burials. At Cann, box leaves were reportedly arranged in a wreath, while at Scole and Chesterford, concentrations of box leaves were reported around the chest and the skull respectively. Similarly, box leaves were found around a cremation urn at Bartlow Hills. ${ }^{76}$ It is possible that these, and other fragments of box leaves from occupation deposits, derive from wreaths of box. Long garlands often featured in portico gardens, made from lengths of ivy, vine 
and smilax, while shorter garlands, wreaths and chaplets were made from scented plants, especially rose and violet, and, in the case of victory wreaths, laurel. ${ }^{77}$ Imported plant foods, such as dates and figs, wooden artefacts and box wood itself are known to have been traded through the Roman world. ${ }^{78}$ However, the plausibility of wreaths of box leaves also being traded is here considered unlikely, as it is far more plausible that these box sprigs were from locally grown plants.

The debate over the native status of box in Britain has a long history. Godwin and, more recently, Mabey believe box to be native, citing charcoal identifications from the Neolithic site of Whitehawk Camp, Brighton, and a Flandrian pollen record from the Lake District, as well as AngloSaxon place-name evidence. However, the dating of the Whitehawk Camp charcoal record is considered dubious due to the presence of Castanea sativa (sweet chestnut), which is thought to be a medieval introduction. ${ }^{79}$

A recent review of box in Europe cites single grain pollen records from three sites in Britain dated to after c. 5000 B.C., albeit supporting this limited evidence with the mortuary evidence from Roman Britain, to argue for a native status. ${ }^{80}$ In Sussex, a single pollen grain was identified from a pollen core taken from the Caburn valley, the level dated to 7217-6939 cal BP. A pollen sequence from Stafford had a single pollen grain, interpreted as dating to the Late Iron Age/Early Roman period, and a single pollen grain was recovered from Ellerside Moss, Lancashire. ${ }^{81}$ These are all sites where local areas of steep calcareous slopes, suitable for box, were present. The Strata Florida manikin, a figurine carved from boxwood and recovered from central Wales, has also been radiocarbon dated to 43 B.C.A.D. $67 .{ }^{82}$ These finds indicate that there was a small established population of box in Britain. In contrast, Coates has recently suggested that box was a Roman introduction to Britain based on the cooccurrence of villa sites with place names stemming from box, such as Boxmoor villa. They offer the interpretation that so-called native box populations in these locations resulted from the planting of box in the Roman period. ${ }^{83}$ A recent review of the status of box in northern France has also concluded that the shrub was introduced in the Roman period. ${ }^{84}$

Considering the spatial distribution of the box records synthesised in this paper, the site distribution is not a reflection of the underlying geology, as these settlements are not all on calcareous soils. The occurrence of box at archaeological sites in the non-calcareous areas of London, Silchester, York, as well as the Upper Thames and Ouse valleys, clearly show that these are unlikely to be wild 
occurrences. However, it must be noted that calcareous soils are free draining, making the presence of waterlogged sediments and, hence, the recovery of box macrofossils very unlikely. The only finds from calcareous regions are leaves from a burial at Cann and charcoal from Westhawk Farm, Kent. While the native status of box continues to be debated, it is clear from this review of the Roman archaeobotanical data that the presence, and inferred use, of box plants on settlements is a phenomenon first recorded archaeologically in the Roman period and hence represents a major change in human relationships with box. Given the very limited presence of box prior to the Roman period, it seems plausible that at least some of the box plants growing in towns, villas and rural farmsteads were imported from the continent rather than transplanted from the wild.

Norway spruce was present in central and north-east Europe by the Roman period, while no archaeobotanical records have been recorded in Holocene Britain before the Roman period. ${ }^{85}$ Likewise, Pinus pinea is only native to the Mediterranean region, with no archaeobotanical records in Britain before the Roman period. ${ }^{86}$ Positive evidence for the trade in stone-pine cones derives from the widespread occurrence of stone-pine cones and nutshells from regions beyond the native distribution of $P$. pinea, from the Eastern Desert of Egypt to Roman Britain. The find of 61 closed pine cones from a first-century B.C. shipwreck recovered off of the coast of Toulon, southern France, provides direct evidence for their trade. ${ }^{87}$ A Roman pottery shop at Colchester, destroyed during Boudica's rebellion in A.D. 60/61, produced evidence for various imported foods (lentils, figs, anise) as well as 27 nut shells and nine bracts, showing the early import of pine nuts to Roman Britain. ${ }^{88}$ Kernels can survive for a long time within unopened nuts, while the extra transport costs of transporting unopened pine cones as opposed to extracted nuts is sizeable. ${ }^{89}$ Hence, the recovery of pine cone bracts and intact, unopened cones strongly suggests that whole cones were purposefully imported. It is also possible that some pine cones were imported as plugs within wine amphorae. A shipwreck discovered at Albenga in Italy contained several wine amphora sealed with pine cones. Columella suggested that the pine cones may have also been used to perfume and conserve the wine. ${ }^{90}$ However, the more common materials used as amphora stoppers were cork, ceramic discs and wood..$^{91}$

The vast majority of archaeobotanical records are only of pine cones with no needles or wood and, given the evidence presented in the previous paragraph, all are likely to have been imported. There are, though, two exceptions. At the Guildhall amphitheatre, London, branches identified as Pinus sp. 
were recorded as lining a ditch located outside the eastern entranceway of the amphitheatre. Several pine cones were recovered from the base of the ditch. The branches appeared to have been freshly cut, with branchlets and bark still attached, suggesting that a pine tree was growing locally and that the branches may have been prunings from this tree. ${ }^{92}$ Considering the rareness of stone-pine cones and pine branches, it seems highly likely that these items derive from the same single stone-pine tree. The second site is Clatterford Roman villa on the Isle of Wight, where a stone-pine cone was recovered from a ditch to the south of the main villa building dating to the late third-early fourth century, where Pinus sp. pollen was also recorded in samples from a trench to the south-east of the villa from a late third-century peat layer. ${ }^{93}$ Scot's pine (Pinus sylvestris) is considered to be absent from southern Britain at this point, but the pollen could have conceivably been transported long distance by wind or trapped in the pine cone. ${ }^{94}$ Elsewhere, the frequency with which stone-pine remains have been recovered in Kent, an area of calcareous soils suitable for stone-pine trees, has been held as good evidence for the presence of stone-pine trees in the Roman period. ${ }^{95}$ The presence of a charred pine nut shell in an early fifth-century hearth at Fullerton villa, ${ }^{96}$ in the Test valley, is intriguing given the substantial decrease in trade in this period. Beyond the specific example of the London amphitheatre, it is currently unclear to what extent stone-pine trees would have been encountered in Roman Britain.

\section{The Meaning of Evergreen Plants}

The evidence for the presence of introduced evergreen plants in Roman Britain, both in part and in their entirety, leads to the questions of what were the meanings of these plants and why were the plants and plant items imported. The abundant evidence for pine cones in the material culture record provides numerous inferences on their meaning. Stone-pine cones are clearly associated with mourning and the afterlife. ${ }^{97}$ They occur on numerous mortuary monuments, including tombstones at Brough, Cumbria, and Overborough, Lancashire, as well as carved in limestone from within a walled cemetery in Roman Southwark. ${ }^{98}$ Pine cones are also strongly linked with regeneration and water, occurring commonly as finials on fountains well into the medieval period. This trend begins in the Roman period, most iconically on the Fontana della Pigna in the Vatican City, but also on a bronze water fountain from Pompeii. ${ }^{99}$ Pine cones also have clear associations with numerous deities, featuring as incense in Mithraic rituals. The pine tree is central to the myth of Attis and Cybele, with pine cones featuring on 
a bronze figurine of Attis from London, on a pine branch held in a bronze hand from a Romano-Celtic temple at Hockwold-cum-Wilton on the fen edge, and on a pine tree depicted on a Cybele altar from London. The Triangular Temple in Verulamium, where charred pine remains were recovered, has also been associated with Cybele. Pine cones also feature on copper-alloy hands linked to the god Sabazios, while Silvanus is often depicted with pine cones of fruit within a mantle. ${ }^{100}$ Pine cones also feature occasionally in scenes of religious offerings, such as on a relief from Rome dedicated to Claudius Gothicus, on a third-century altar from Rome, or in the lararium painting at the Caupona of Euxinus, Pompeii. ${ }^{101}$

Box leaves feature less explicitly in religious life in the Roman world and do not appear as a common symbol or motif. The literary mentions of box clearly depict the plant's use in high-status ornamental gardens in Italy. Pliny describes in detail how to take cuttings of box for topiary bushes and Pliny the Younger's description of his own garden layout had box hedges separating paths. In fact, the selection of box as an ornamental garden plant has been attributed largely to its suitability for topiary. While box does feature in fresco garden scenes, such as at the villa of Livia, box was a native shrub of Italy. Unlike trees such as cherry, plane and citrus it does not feature in the discussion of botanical imperialism whereby new species and varieties were introduced to Italy following military victories, sometimes explicitly featuring in military triumphs and being planted in public horti and the homes of the wealthy. ${ }^{102}$ Box wood is considered to have been a synonym for paleness. Box sprigs are used in the modern period as grave decoration and at funerals, while in France, box is associated with immortality and eternity. ${ }^{103}$ The cultivation of box shrubs in Roman Britain has been seen as a general indicator of an elite strategy of adopting 'Roman' status symbols, ${ }^{104}$ yet the broader associations with mortality, combined with the mortuary evidence from Roman Britain, shows that the shrub had a more diverse range of meanings.

Beyond explicit religious and literary associations, a broader range of evidence highlights the significance of evergreen plants in the past. Molecular analysis of resinous substances recovered from Late Roman 'package' burials across Britain have identified the presence of exotic resins including Pistachia sp. (mastic/terebinth), Boswellia sp. (frankincense/olibanum) and Pinaceae resins. ${ }^{105}$ More broadly, the presence of ornamental gardens of exotic plants, alongside the evidence for game parks, has been interpreted as an association of the exotic with the sacred. ${ }^{106}$ Evergreen shrubs have also been 
argued as having been sacred in the Iron Age. For example, a statue of a leader from the Glauberg, Hesse, had a head dress of the parasitic evergreen shrub mistletoe, while Pliny comments that mistletoe was sacred to Gaulish druids. The occurrence of holly and mistletoe alongside quern stone fragments, shoes and writing tablets in wells has been suggested as significant, due to the occurrence of these plants in the gut contents of Lindow Man, found in late first-century B.C. to second-century A.D. Cheshire. ${ }^{107}$ There is clearly a wide range of deities and meanings associated with evergreen plants, precluding the establishment of any single meaning from the recovery of plant remains. Furthermore, material-culture studies have shown that an object has no inherent single meaning, but rather meanings are historically situated and are contingent upon interactions with events and people, which in turn varies upon a wide range of factors such as status, age and gender. ${ }^{108}$ In order to investigate the significance of introduced evergreen plants and pine cones in Roman Britain, it is perhaps more useful to consider how these trees and objects affected human experience, rather than what they meant or why they were grown.

\section{Detecting the Planty Agency of Box}

The review of archaeobotanical evidence for the presence of introduced evergreen plants in Roman Britain has clearly demonstrated that some people, living in towns, villas and rural farmsteads, were dwelling alongside box plants, while a very limited number of people were living alongside the entirely new plants stone-pine and norway spruce. Recent work in the areas of cultural geography and anthropology has both encouraged a change in how we perceive the agency of plants in relation to humans and presented a range of characteristics of plants which can be considered within an archaeological context. These developments closely parallel studies within the developing field of classical, multi-sensory studies, which have considered the olfactory aspects of plants. ${ }^{109}$ Propositions for the active agency of plants in relationship to humans stem from philosophical considerations of how plants have been sidelined in western thought, advances in identifying how plants are reactive and affective organisms within chemistry and biology, and the use of the relational approach stemming from the object-focused studies inspired by the works of Latour and Gell to consider all people, objects and animals as being related, to the extent that 'objects and animals are actively involved in the processes of our world'. ${ }^{110}$ Applying such relational approaches to plant remains has been recently 
conceived as 'plant materiality', but applications of these approaches have so far been limited. ${ }^{111}$ Nearly a decade ago, Jones and Cloke argued for the need to be serious in the application of materiality to nature and, more recently, Head et al. have stated that 'Attention to the specific capacities of plants is important to understand the specifics of relationality and distributed agency in human-plant encounters'. ${ }^{112}$ To do so, it is necessary to highlight particular material characteristics of plants which can be applied to archaeobotanical material.

Within the field of human-plant studies, several features of plants have been shown as key to affecting humans in some way. Here it will be demonstrated that these can be usefully applied to archaeobotanical material. Indeed, a major advantage of applying relational approaches to plant remains is that we can easily move from the species identification of a plant macrofossil, to having a fairly accurate understanding of the vibrancy the source plant had in its past life in terms of colour, temporality, smell, tactility and growth structure. Although, it must be emphasised that attempts to detect planty agency are still developing, that is the effect of unique characteristics of plants on people, ${ }^{113}$ here the factors of visual appearance, smell, physicality and temporality are considered in relation to archaeological evidence for imported evergreen plants. The visual appearance of plants within gardens is highlighted in ethnographic studies of gardeners in Britain, for instance Hitchings' ethnographic work in allotments which showed that people became attached to plants with perceived greater aesthetic qualities. ${ }^{114}$ Pitt focused on observations of the visual aspects of plants through timelapse photography within community gardens to detect changes in the growth of seedlings and changes in foliage and flowers, which alerted her to planty agencies. ${ }^{115}$

While not prominent within cultural geography, olfactory senses have received focus within classical multi-sensory studies. Smell is a pervasive sense which freely enters the body. The reception of smell is specific to individuals and cultures, yet techniques such as sensory maps have proved useful in considering the organisation of urban societies and the quality of life of the inhabitants. ${ }^{116}$ Recently, Draycott has highlighted how evergreen plants, such as box, as opposed to deciduous plants, would smell all-year round. ${ }^{117}$ The physical aspects of plants, that is their growth habit and form of reproduction, have also been shown to affect the formation of human-plant relationships. For instance, the selection of plants on pedestrian streets in Paris affected how people inhabited these streets, changing them from places of movement to places of dwelling. ${ }^{118}$ Binding these aspects of plant 
materiality together is the temporality of plants, notably considered by Ingold, allowing us to consider how daily, seasonal and annual rhythms of plants affect humans and bind them up within the life of a plant. For example, a recent study of Australian vineyard workers encapsulated how the 'ecological temporalities' of plants, namely temporal changes in smell, colour and fruiting time, strongly affected the labour patterns and emotions of workers. ${ }^{119}$

Considering these aspects of the most widely occurring plant, box, we can gain insights into how box would have contrasted with the wider flora of Britain and the effects this might have had on people. Box has glossy green leaves (FIG. 10), which remain on the shrub throughout the year. Small white flowers appear in the spring, but the shrub has largely the same appearance year round. Box has a highly distinctive smell, described by Mabey as 'malodorous', ${ }^{120}$ due to the presence of certain phenolic compounds, the production of which subtly varies with season. ${ }^{121}$ Box shrubs are slow growing, but long lived, and can be grown easily from small cuttings. Plants typically reach up to $5 \mathrm{~m}$ tall, with dense foliage and toxic leaves unpalatable to herbivores. ${ }^{122}$ Unifying these aspects is the temporality of box shrubs. Their appearance remains the same throughout the annual cycle, in contrast to the majority of deciduous plants in Britain. Furthermore, the long life-span of box means we can see shrubs as permanent fixtures in the lives of humans, in the same way that the temporality of Ingold's pear-tree is 'consonant with that of human dwelling'. ${ }^{123}$ Several evergreen plants were native to Britain: holly, yew and juniper, and scot's pine surviving in Scotland. The evergreen nature of these plants means they represent the same ecological temporality as Box. However, box differs by being more compact in its growth habit, non-edible to animals and a new occurrence in most areas of Roman Britain. While the archaeobotanical record of these native evergreen plants has not been interrogated, the argument for box as a Roman introduction presented in this paper, combined with the evidence for this shrub being present within settlements, shows that new human-plant relationships would have been experienced. 


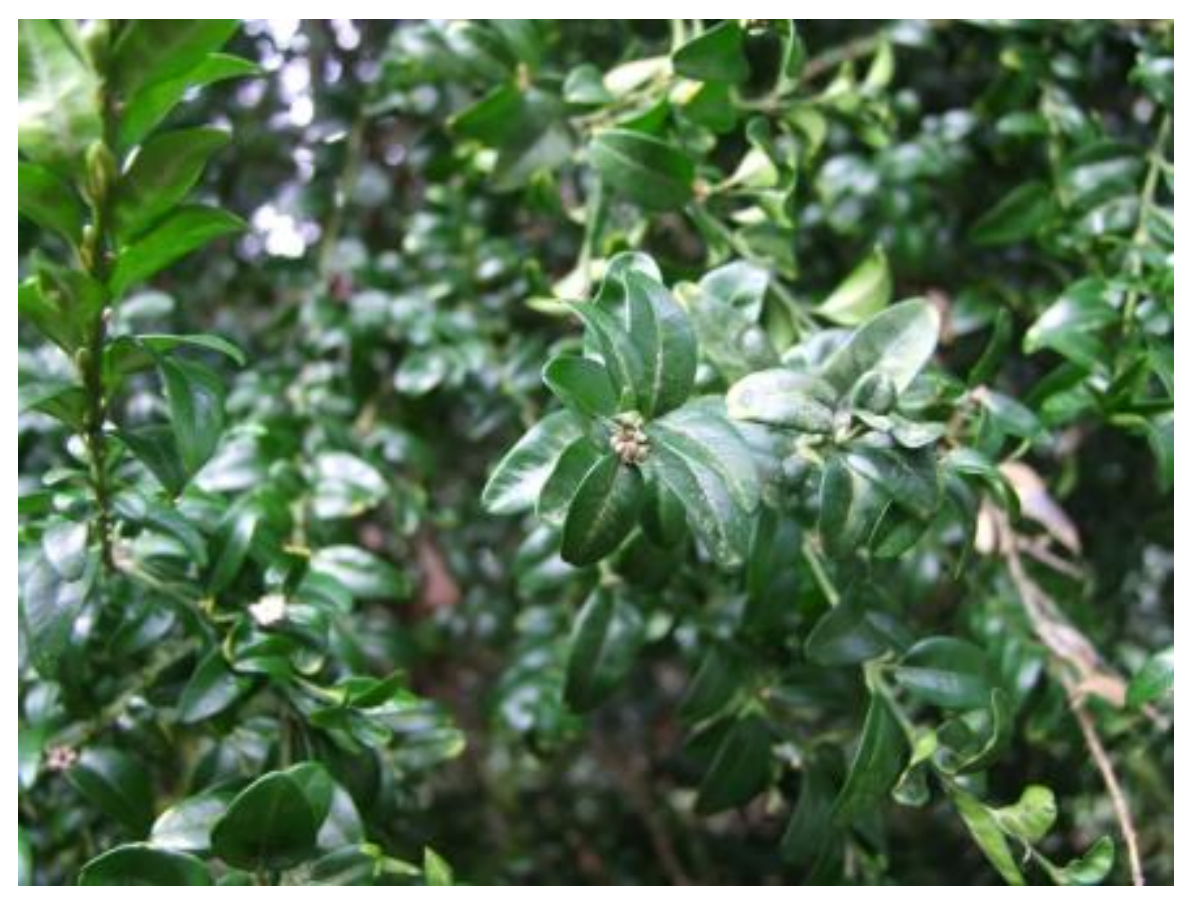

FIG 10. Image showing the leaves and flower buds of a box shrub.

Keeping these planty agencies in mind, the box shrub, which can be considered to have been growing on the edge of a busy road through Roman London at 1 Poultry, can be seen as acting as a physical barrier between a private property and a public thoroughfare; ${ }^{124}$ a boundary which would not be damaged by animals and would provide both a physical and visual barrier between public and private property. Yet the distinctive visual and olfactory aspects of box, which contrast strongly with other native flora in Britain, would mean that this area of town had a distinctive multi-sensory landscape in comparison with other parts, while also encouraging people to dwell within the space and consider the novelty of a plant rarely encountered. The differing temporalities of box would mean that the sense of time and dwelling within the world would subtly differ between those urban inhabitants and visitors to London, Silchester and York, who were experiencing this plant on a daily basis and the inhabitants of rural Roman Britain. Box has been recorded at five villas, as well as Fishbourne, and only four farmsteads, which given the far larger number of farmsteads studied archaeobotanically than villas, shows a contrast also between the ecological temporality of high-status villa dwellers and farmers. Where box has been recorded at farmsteads, the presence of leaves and fruit fragments at Farmoor and Claydon Pike suggests the plants were perhaps not managed as they were at the many urban and villa sites where only leaves are recorded, while the most common interaction of farmers 
with the natural world might have lessened the contrast between the temporality of box and that of the few native evergreen plants. Not only would urban and high-status villa dwellers be no longer included in the cycles of agricultural time, they would be encountering a new plant which obscures temporal changes between the seasons.

This section has followed material-culture studies by extending relationality to plants and considering physical characteristics of Box as aspects of plant materiality. However, to truly advance the study of the Roman world, we need to consider what is distinctive about what plants did, as opposed to what material culture such as terra sigillata, or lamps, or brooches did. The key aspects of plant materiality that have been highlighted - temporality and smell - are on the basis that a plant is a living being, grounded in the ecological world. While plants could be translocated across the Roman world for a range of human motivations, once planted in the ground they created a new ecological niche, becoming enmeshed in the soil and the ecosystem. Following this train of thought, we can advance that plants did two key things. First, they changed the local environment, in terms of biodiversity, soil characteristics, insects and animals. Being tethered to the spot, plants would have affected the daily experience of thousands of people, in contrast to the personal relationships of individuals with portable material culture. The changes that plants made to the lived environment of the settlement would have thus affected the way the wider community experienced the world, as well as factors of health and well-being. The second point is that by being a living life form, box also became part of the living legacy of Roman Britain. Box became increasing common through the Roman period (FIG 4.) and made a long-term contribution to the vegetation communities and landscape of the island. ${ }^{125}$

\section{Ritualised Deposition and Sensory Experience}

In the case of stone-pine cones, it is possible to consider the sensorial aspects of ritualised activities due to the recovery of the in-situ remains of offerings from several temples in Roman Britain. Whole stone-pine cones and pre-prepared stone-pine cone incense were being used within burnt offerings. Further to the considerations above of the experience of smell within urban space, Hamilakis has written on the sensory experience within Mycenaean sanctuaries, whereby the marked sensory experiences of burning flesh within dark enclosed spaces would have produced a strong and unified experience for those participating in the ceremonies. ${ }^{126}$ Smellscapes would be very variable and 
affected by a myriad of local conditions, such as wind and architecture. ${ }^{127}$ The distribution of the smell of burning pine cones thus would have been affected by the condition and quantity of pine cones, how they were burnt, where the offering took place and, above all, the lived experience of the individual making the offering. The consideration of the sensorial aspects of pine cone smells does, though, increase our understanding of the effects of offerings in past places.

While the burning of plant material and wood occurred on a daily basis in Roman Britain, in the hearth, corn-drier or hypocaust, offerings of stone-pine cones would have produced a distinct sensory experience. Pine trees are considered to have been absent from southern Britain by at least 2000 B.C., ${ }^{128}$ and stone-pine cones were rare imports. Stone-pine cones have a distinctive smell due to the presence of the compounds limonene and $\alpha$-pinene. ${ }^{129}$ Where spatial evidence is available, records show that the remains of offerings containing stone-pine cones occurred within closed spaces, for instance in the Triangular Temple, Verulamium and at the Carrawburgh Mithraeum. At the first of these, charred pine cone remains were deposited within various pits within the temple, while at the Carrawburgh Mithraeum they were buried beneath new altars, or, in the case of pre-prepared pine cones, stored in an enclosed bunker. ${ }^{130}$ These patterns indicate that the sensory experience of offering pine cones would have been restricted to the individuals visiting the temple, perhaps within a few hours. Beyond the strong and exotic smell, the visual aspects of flickering light produced by burning stone-pines would also heighten the sensory experience. In contrast, offerings made at the military enclosure at Orton's Pasture, Staffordshire, were conducted in the open, where we can imagine the smell from at least one burning pine cone drifting over the wider military camp. ${ }^{131}$ Intriguingly, the deposition of the charred pine cones remains took place within a pit where layers of sand separated separate offerings. Once the strong multi-sensory aspects of the offering were experienced, the smell was soon closed off.

\section{Evergreen Plants beyond Britain}

The archaeobotanically well-studied province of Britannia has been the focus of this article, but evergreen plants were also being encountered in ornamental gardens and ritual activities across the Roman world. Examples are presented here which indicate the range of locations in which ornamental plants have been recorded. ${ }^{132}$ From Italy, a growing body of archaeobotanical data is beginning to 
provide evidence against which that of frescoes and literary evidence can be compared. At Modena, on the southern edge of the Po valley, box pollen has been identified from the Ex cinema capitol site, while waterlogged plant remains of cypress (Cupressus sempervirens), myrtle (Myrtus), plane (Platanus) and yew (Taxus) have been identified from the site of a Roman domus. ${ }^{133}$ In Sicily, the presence of box shrubs has been suggested at the Greco-Roman theatre at Taormina, albeit the Buxus pollen was identified from undated pollen cores. ${ }^{134}$ Plant macrofossils of box are also known from France and Germany. Excavations at a rural nucleated settlement at La Queue de Rivecourt, in the north-east of the Paris basin, recovered leaves and a seed of box, as well as an intact pine cone from a large pit near to some small private baths. This finding was reported as only the second find of box in France and was interpreted as evidence of a box shrub growing nearby. ${ }^{135}$ In Germany, box leaves, seeds and pollen were identified from a villa at Wiesweiler in the middle Rhine region. ${ }^{136}$ In Cologne, waterlogged box leaves have been recovered from a borehole sample in an area beyond the Roman town walls on the west bank of the Rhine, dated to the first/second century, while there are also unpublished finds from Xanten. ${ }^{137}$

Archaeobotanical evidence for Pinus pinea in Europe corresponds with the evidence from Britain of pine cones being used in both ritualised and culinary contexts. The most recent summary of central Europe, which reported Pinus pinea remains in fewer than ten sites out of a database of 400, includes finds from both domestic contexts at the villa at Worb-Sunnhalde, Switzerland, at Vindonissa and from temple contexts in Mainz, Empel and Nijmegen. ${ }^{138}$ Subsequently, the identification of Pinus pinea nutshell and cones has been reported from wider areas of Europe. In Rome, stone-pine cones were recovered from the fountain of Anna Perenna, alongside offerings of curse tablets, oil lamps and lead containers with figurines. ${ }^{139}$ Pinus pinea remains have also been recovered from the east of the empire, from settlements in Bulgaria, including the necropolis at Apolonia and the fort of Abritus, in Croatia at Veli Brijun, in Caesarea harbour, Israel, and from Quseir al-Qadim, Egypt. ${ }^{140}$ A full review is beyond the scope of this paper, but it is clear that stone-pine cones were being traded throughout the Roman world. Unlike box, there is no known evidence for the ornamental planting of pine trees in Europe beyond their native distribution. 


\section{CONCLUSIONS}

This synthesis of archaeobotanical data from a Roman province, which has benefited from intensive archaeobotanical investigation, has shown that the movement of ornamental plants into the northwestern provinces was occurring in parallel with the movement of fruit and nut trees. There is widespread evidence for the cultivation of box, with the strong likelihood that some shrubs were introduced from the continent, while box became a common feature in towns from the second century onwards. Norway spruce trees were introduced to Roman Britain on a small scale and there is debatable evidence for the cultivation of stone-pine trees in London. While stone-pine and, to a lesser extent, box have varied strands of meaning, drawn from literary and artefactual evidence, a consideration of plant materiality, that is the visual, olfactory and temporal aspects of these evergreen shrubs, has provided new insights into how they affected the experience of life for those encountering them in towns and in temples. We can never know what people experienced in the past, sensory reception being socially situated, but by at least starting from the point of known physical characteristics of plants, we can at least explore the variation in certain sensory experiences. The consideration of plants as vibrant, living beings could also contribute in the future to numerous strands of study, including globalisation studies, the articulation of social status, funerary activities and the manipulation of the built environment, as well as long-term ecological studies, which currently overlook the introduction of evergreen plants. ${ }^{141}$

The long-term impact of these plants in Britain is variable. Unlike stone-pine and norway spruce, populations of box shrubs are known from written evidence from the Domesday period and are now considered a native aspect of British flora. In order to more fully evaluate the changing humanplant relationships, biomolecular methods, namely aDNA, will be required to establish the origins of present and past populations of box in Britain. There is growing evidence for the cultivation of introduced evergreen plants elsewhere in the Roman world, hence the continued application of archaeobotanical methods is vital to allow the evidence from Britain to be evaluated more broadly. It is hoped that the archaeobotanical evidence presented here will inform the discussions based upon the literary, artistic and architectural evidence for plant introductions to and from Italy. Much work within the Roman world over the last decade has focused on demonstrating the material agency of objects. It is perhaps time to give more consideration to the living beings in the Roman world. 


\section{ACKNOWLEDGEMENTS}

This paper draws on ideas developed over several years and developed through several papers given within RAC/TRAC and TAG conference sessions. I am grateful for those who supplied data and references (Gill Campbell, Dana Challinor, Thomas Derrick, Hella Eckardt, Mark Robinson, Dan Young) and to those who discussed the potentials for plant agency in archaeology and Roman gardens (Ben Geary, Annalisa Marzano, James Morris, Suzi Richer). I am grateful to Michael Fulford for comments on the text and the stimulating comments of two anonymous reviewers. All faults remain my own.

Department of Archaeology, University of Reading

1.a.lodwick@reading.ac.uk

APPENDIX TABLE 1. RECORDS OF BOX MACROFOSSILS IN ROMAN BRITAIN

\begin{tabular}{|c|c|c|c|c|c|c|}
\hline Site & Location & Site type & Period & Parts preserved & Context & Reference \\
\hline 1 Poultry & London & Major Town & $\begin{array}{l}\text { A.D. } 250- \\
300\end{array}$ & Waterlogged leaves & Road surface & Davis 2011,530 \\
\hline $\begin{array}{l}12 \text { Arthur } \\
\text { Street }\end{array}$ & London & Major Town & $\begin{array}{l}\text { A.D. } \\
120 / 5- \\
180 / 200 \\
\end{array}$ & Waterlogged leaves & $\begin{array}{l}\text { Waterfront } \\
\text { infill deposits }\end{array}$ & Roberts 2008 \\
\hline $\begin{array}{l}\text { 132-7 Upper } \\
\text { Thames Street }\end{array}$ & London & Major Town & Roman & Waterlogged leaves & - & $\begin{array}{l}\text { Cowan and } \\
\text { Hinton } 2008\end{array}$ \\
\hline $\begin{array}{l}15-35 \\
\text { Copthall } \\
\text { Avenue } \\
\end{array}$ & London & Major Town & Roman & Waterlogged leaves & - & $\begin{array}{l}\text { Maloney and de } \\
\text { Moulins 1990, } \\
85\end{array}$ \\
\hline $\begin{array}{l}30 \text { Gresham } \\
\text { Street }\end{array}$ & London & Major Town & Roman & Waterlogged leaves & - & $\begin{array}{l}\text { Cowan and } \\
\text { Hinton } 2008\end{array}$ \\
\hline Bartlow Hills & Cambridgeshire & Cremation & $\begin{array}{l}\text { Late } \\
1 \text { st/early } \\
2 \text { nd } \\
\text { century }\end{array}$ & $\begin{array}{l}\text { Leaves and } \\
\text { branches entwined } \\
\text { around lamp, leaves } \\
\text { adhering to base of } \\
\text { cremation urn and } \\
\text { surrounding area }\end{array}$ & $\begin{array}{l}\text { Cremation urn } \\
\text { within } \\
\text { tumulus }\end{array}$ & $\begin{array}{l}\text { Gage 1839; } \\
\text { Eckardt et al. } \\
2009\end{array}$ \\
\hline Bedern & York & Major Town & $\begin{array}{l}\text { A.D. 300- } \\
450\end{array}$ & $\begin{array}{l}\text { Waterlogged leaf } \\
\text { fragments }\end{array}$ & Well fill & $\begin{array}{l}\text { Kenward et al. } \\
1986,263\end{array}$ \\
\hline Cann & Dorset & Burial & Roman & $\begin{array}{l}\text { Large numbers of } \\
\text { leaves and short } \\
\text { sprigs at head end, } \\
\text { interpreted as a } \\
\text { wreath of box } \\
\text { leaves }\end{array}$ & $\begin{array}{l}\text { Childs burial } \\
\text { in a lead } \\
\text { coffin }\end{array}$ & Gray 1918 \\
\hline $\begin{array}{l}\text { Chesterford } \\
\text { Churchyard }\end{array}$ & Essex & Burial & Roman & $\begin{array}{l}\text { Intact leaves and } \\
\text { twigs }\end{array}$ & $\begin{array}{l}\text { Leaves in soil } \\
\text { around } \\
\text { inhumation, } \\
\text { near skull and } \\
\text { vase }\end{array}$ & $\begin{array}{l}\text { Gage } 1839 ; \\
\text { Walters and } \\
\text { Stow 2001, } 126\end{array}$ \\
\hline Chew Park & Somerset & $\begin{array}{l}\text { Complex } \\
\text { Farmstead }\end{array}$ & $\begin{array}{l}\text { A.D. } 300- \\
50\end{array}$ & $\begin{array}{l}\text { Waterlogged } \\
\text { worked wood, inner } \\
\text { bark and leaves }\end{array}$ & $\begin{array}{l}\text { Villa well, } \\
\text { south-east of } \\
\text { winged }\end{array}$ & $\begin{array}{l}\text { Stant and } \\
\text { Metcalfe } 1977\end{array}$ \\
\hline
\end{tabular}




\begin{tabular}{|c|c|c|c|c|c|c|}
\hline & & & & & $\begin{array}{l}\text { corridor } \\
\text { villa/farmstea } \\
\text { d } \\
\end{array}$ & \\
\hline Claydon Pike & $\begin{array}{l}\text { Cotswold Water } \\
\text { Park }\end{array}$ & $\begin{array}{l}\text { Complex/ } \\
\text { Enclosed } \\
\text { Farmstead }\end{array}$ & $\begin{array}{l}\text { Mid-late } \\
\text { Roman }\end{array}$ & $\begin{array}{l}\text { Waterlogged leaves, } \\
\text { seeds, flower buds, } \\
\text { twigs and fruits }\end{array}$ & $\begin{array}{l}\text { Waterhole, pit } \\
\text { and drainage } \\
\text { sump }\end{array}$ & $\begin{array}{l}\text { Robinson 2007, } \\
361\end{array}$ \\
\hline $\begin{array}{l}\text { Drapers } \\
\text { Garden }\end{array}$ & London & Major Town & $\begin{array}{l}\text { Second } \\
\text { half of } \\
\text { first } \\
\text { century }\end{array}$ & Waterlogged leaves & Ditch & $\begin{array}{l}\text { Batchelor et al. } \\
2011 \\
\text { Butler and } \\
\text { Ridgeway } 2009\end{array}$ \\
\hline Farmoor & Oxfordshire & $\begin{array}{l}\text { Enclosed } \\
\text { Farmstead }\end{array}$ & $\begin{array}{l}\text { Fourth } \\
\text { century }\end{array}$ & $\begin{array}{l}\text { Waterlogged leaf } \\
\text { and fruit fragments }\end{array}$ & $\begin{array}{l}\text { Pit and } \\
\text { waterhole } \\
\text { within rural } \\
\text { settlement }\end{array}$ & $\begin{array}{l}\text { Lambrick and } \\
\text { Robinson 1979, } \\
127\end{array}$ \\
\hline Frocester & Gloucestershire & Villa & $\begin{array}{l}\text { Fourth- } \\
\text { fifth } \\
\text { century }\end{array}$ & Charcoal & $\begin{array}{l}\text { Large } \\
\text { masonry } \\
\text { house with } \\
\text { formal garden }\end{array}$ & Price 2000, 258 \\
\hline $\begin{array}{l}\text { General } \\
\text { Accident } \\
\text { Site/Tanner } \\
\text { Row }\end{array}$ & York & Major Town & $\begin{array}{l}\text { A.D. } 150- \\
350\end{array}$ & $\begin{array}{l}\text { Waterlogged leaves } \\
\text { and green twigs }\end{array}$ & $\begin{array}{l}\text { Accumulation } \\
\text { /levelling } \\
\text { deposits, well } \\
\text { fill }\end{array}$ & $\begin{array}{l}\text { Hall and } \\
\text { Kenward 1990, } \\
399\end{array}$ \\
\hline $\begin{array}{l}\text { Godmancheste } \\
\text { r }\end{array}$ & Cambridgeshire & Villa & Roman & Waterlogged leaves & Ponds & Murphy 1998 \\
\hline Insula IX & Silchester & Major Town & $\begin{array}{l}\text { A.D. } 200- \\
50\end{array}$ & $\begin{array}{l}\text { Waterlogged leaf } \\
\text { fragment }\end{array}$ & $\begin{array}{l}\text { Well adjacent } \\
\text { to north-south } \\
\text { street }\end{array}$ & Robinson 2011a \\
\hline Marcham & Oxfordshire & Religious & Roman & Waterlogged leaves & Well & $\begin{array}{l}\text { Kamash, pers. } \\
\text { comm. }\end{array}$ \\
\hline $\begin{array}{l}\text { Marsh Leys, } \\
\text { Kempston }\end{array}$ & Bedfordshire & Farmstead & $\begin{array}{l}\text { Late } \\
\text { 3rd/4th } \\
\text { century } \\
\end{array}$ & $\begin{array}{l}\text { Waterlogged leaf } \\
\text { fragments }\end{array}$ & Well & Robinson 2011b \\
\hline $\begin{array}{l}\text { New Royal } \\
\text { Baths }\end{array}$ & Bath & Religious & $\begin{array}{l}\text { A.D. } 150- \\
60\end{array}$ & Waterlogged twigs & $\begin{array}{l}\text { Ditch, near } \\
\text { possible } \\
\text { formal } \\
\text { gardens }\end{array}$ & $\begin{array}{l}\text { Davenport et al. } \\
2007,33\end{array}$ \\
\hline Piccadilly (50) & York & Major Town & Roman & $\begin{array}{l}\text { Waterlogged leaf } \\
\text { fragment }\end{array}$ & Ditch & $\begin{array}{l}\text { Carrott et al. } \\
1992\end{array}$ \\
\hline $\begin{array}{l}\text { Pit XIII in east } \\
\text { of Town, and } \\
\text { from an area in } \\
\text { the north-east. }\end{array}$ & Silchester & Major Town & Roman & $\begin{array}{l}\text { Text: Waterlogged } \\
\text { leaf clippings, } \\
\text { Collections: } \\
\text { Waterlogged whole } \\
\text { leaves }\end{array}$ & Pit & Lodwick 2016 \\
\hline Regis House & London & Major Town & Roman & Waterlogged leaves & & $\begin{array}{l}\text { Cowan and } \\
\text { Hinton } 2008 \\
\end{array}$ \\
\hline $\begin{array}{l}\text { Roden Down, } \\
\text { Compton }\end{array}$ & Berkshire & Burial & $\begin{array}{l}\text { Post-A.D. } \\
364\end{array}$ & $\begin{array}{l}\text { Leaves and young } \\
\text { stems by head and } \\
\text { legs, and lining the } \\
\text { floor }\end{array}$ & $\begin{array}{l}\text { Floor of lead- } \\
\text { lined wooden } \\
\text { coffin, grave } \\
\text { of Women } \\
50+\end{array}$ & $\begin{array}{l}\text { Allison, 1947; } \\
\text { Hood and } \\
\text { Walton } 1948\end{array}$ \\
\hline Rougier St & York & Major Town & $\begin{array}{l}\text { A.D. } 150- \\
200\end{array}$ & Waterlogged leaves & Ditch & $\begin{array}{l}\text { Hall and } \\
\text { Kenward 1990, } \\
399 \\
\end{array}$ \\
\hline Scole & Norfolk & Inhumation & $\begin{array}{l}\text { Early-mid } \\
\text { second } \\
\text { century }\end{array}$ & Waterlogged leaves & $\begin{array}{l}\text { Child } \\
\text { inhumation. } \\
\text { Isolated burial } \\
\text { south of the } \\
\text { east-west } \\
\text { Roman road, } \\
\text { isolated burial } \\
\text { near to } \\
\text { roundhouse, } \\
2-3 y o \text {. Leaves } \\
\text { of box and } \\
\text { Atropa } \\
\text { belladonna }\end{array}$ & $\begin{array}{l}\text { Fryer and } \\
\text { Murphy } 2014\end{array}$ \\
\hline
\end{tabular}




\begin{tabular}{|l|l|l|l|l|l|l|}
\hline & & & & & $\begin{array}{l}\text { seeds from the } \\
\text { chest area }\end{array}$ & \\
\hline Skeldergate & York & Major Town & $\begin{array}{l}\text { Late } \\
\text { fourth } \\
\text { century } \\
\text { allems, no woody } \\
\text { fragments. } \\
\text { Interpreted dead } \\
\text { leaves, not clippings }\end{array}$ & $\begin{array}{l}\text { Waterlogged leaves, } \\
\text { all fetached from }\end{array}$ & $\begin{array}{l}\text { Well, } 6 \text { out of } \\
\text { fills }\end{array}$ & $\begin{array}{l}\text { Hall } \text { et al. 1980, } \\
144\end{array}$ \\
\hline Stanwick & Northamptonshire & Villa & $\begin{array}{l}\text { Third and } \\
\text { fourth } \\
\text { century }\end{array}$ & $\begin{array}{l}\text { Waterlogged leaves } \\
\text { and stalks }\end{array}$ & Wells & Campbell 1995 \\
\hline Stonea & Cambridgeshire & $\begin{array}{l}\text { Roadside } \\
\text { settlement }\end{array}$ & $\begin{array}{l}\text { A.D. 140- } \\
220\end{array}$ & Charred leaflet & - & $\begin{array}{l}\text { Van der Veen } \\
1996\end{array}$ \\
\hline $\begin{array}{l}\text { Westhawk } \\
\text { Farm }\end{array}$ & Ashford, Kent & $\begin{array}{l}\text { Roadside } \\
\text { settlement }\end{array}$ & Roman & Charcoal & $\begin{array}{l}\text { Ditch, hearth } \\
\text { and pits }\end{array}$ & Challinor 2008 \\
\hline $\begin{array}{l}\text { Winterton } \\
\text { Villa }\end{array}$ & Lincolnshire & Villa & Roman & $\begin{array}{l}\text { Waterlogged leaf } \\
\text { clippings }\end{array}$ & - & $\begin{array}{l}\text { Lambrick and } \\
\text { Robinson 1979, } \\
127 ; \text { Dimbleby } \\
1978,96\end{array}$ \\
\hline
\end{tabular}

APPENDIX TABLE 2. RECORDS OF STONE-PINE MACROFOSSILS IN ROMAN BRITAIN

\begin{tabular}{|c|c|c|c|c|c|c|}
\hline Site & Location & Site type & & Parts preserved & Context & Reference \\
\hline 1 Poultry & London & Colonia & $\begin{array}{l}\text { A.D. } 65- \\
125\end{array}$ & $\begin{array}{l}\text { Waterlogged intact } \\
\text { cones, loose bracts } \\
\text { and nut shells }\end{array}$ & $\begin{array}{l}\text { Dumps around } \\
\text { water tank }\end{array}$ & Davis 2011 \\
\hline 45-46 High St & Colchester & Fortress & $\begin{array}{l}\text { A.D. } \\
60 / 61\end{array}$ & $\begin{array}{l}\text { Charred nut shells } \\
\text { and bracts }\end{array}$ & Pottery shop & $\begin{array}{l}\text { Murphy 1984, } \\
32\end{array}$ \\
\hline $\begin{array}{l}\text { Alchester } \\
\text { Vexillation } \\
\text { Fortress }\end{array}$ & Alchester & Fortress & c. 47 A.D. & $\begin{array}{l}\text { Waterlogged cone } \\
\text { fragments and nuts }\end{array}$ & $\begin{array}{l}\text { Fort ditch } \\
\text { sediments }\end{array}$ & $\begin{array}{l}\text { Booth et al. } \\
2007,281\end{array}$ \\
\hline Bancroft villa & Buckinghamshire & Villa & Roman & Waterlogged cone & $\begin{array}{l}\text { Ditch fill, to } \\
\text { south of } \\
\text { enclosure and } \\
\text { rectangular } \\
\text { structure }\end{array}$ & $\begin{array}{l}\text { Pearson and } \\
\text { Robinson } 1994\end{array}$ \\
\hline $\begin{array}{l}\text { Billingsgate } \\
\text { Buildings }\end{array}$ & London & Major Town & $\begin{array}{l}\text { Late first- } \\
\text { early } \\
\text { second } \\
\text { century }\end{array}$ & $\begin{array}{l}\text { Waterlogged bracts } \\
\text { and nuts }\end{array}$ & - & $\begin{array}{l}\text { Willcox 1977; } \\
1980\end{array}$ \\
\hline $\begin{array}{l}\text { Bustum burial, } \\
\text { Watling Street }\end{array}$ & $\begin{array}{l}\text { Southwark, } \\
\text { London }\end{array}$ & Major Town & $\begin{array}{l}\text { Late } \\
\text { first/early } \\
\text { second }\end{array}$ & $\begin{array}{l}\text { Charred nut shells, } \\
\text { bracts, central part } \\
\text { of cone }\end{array}$ & $\begin{array}{l}\text { Bustum burial } \\
\text { pit }\end{array}$ & Giorgi 1997 \\
\hline $\begin{array}{l}\text { Carrawburgh } \\
\text { Mithraeum }\end{array}$ & Hadrian's Wall & Religious & $\begin{array}{l}\text { Third } \\
\text { century }\end{array}$ & $\begin{array}{l}\text { Charred intact cone } \\
\text { and derived fuel }\end{array}$ & Mithraeum & $\begin{array}{l}\text { Blackburn } \\
\text { 1951; Smythe } \\
\text { 1951 }\end{array}$ \\
\hline $\begin{array}{l}\text { Cathedral Car } \\
\text { Park }\end{array}$ & Winchester & Major Town & $\begin{array}{l}\text { A.D. } 250- \\
300\end{array}$ & $\begin{array}{l}\text { Waterlogged intact } \\
\text { cone }\end{array}$ & Well & $\begin{array}{l}\text { Biddle and } \\
\text { Quirk 1964; } \\
\text { Murphy 1977 }\end{array}$ \\
\hline $\begin{array}{l}\text { Chew Valley } \\
\text { Lake }\end{array}$ & Somerset & $\begin{array}{l}\text { Complex } \\
\text { farmstead }\end{array}$ & $\begin{array}{l}\text { c. A.D. } \\
300-50\end{array}$ & $\begin{array}{l}\text { Bracts and nut } \\
\text { shells }\end{array}$ & Well & $\begin{array}{l}\text { Rahtz and } \\
\text { Greenfield } \\
1977,366 \\
\end{array}$ \\
\hline Clatterford Villa & Isle of Wight & Villa & $\begin{array}{l}\text { Late third } \\
\text { century }\end{array}$ & $\begin{array}{l}\text { Waterlogged intact } \\
\text { cone }\end{array}$ & Ditch & $\begin{array}{l}\text { Busby et al. } \\
2001\end{array}$ \\
\hline Claydon Pike & Gloucestershire & $\begin{array}{l}\text { Complex } \\
\text { farmstead }\end{array}$ & $\begin{array}{l}\text { Early } \\
\text { second to } \\
\text { early } \\
\text { fourth } \\
\text { century }\end{array}$ & $\begin{array}{l}\text { Waterlogged intact } \\
\text { cone }\end{array}$ & Waterhole & $\begin{array}{l}\text { Robinson 2007, } \\
361\end{array}$ \\
\hline $\begin{array}{l}\text { Copthall } \\
\text { Avenue }\end{array}$ & London & Major Town & $\begin{array}{l}\text { Early- } \\
\text { mid- } \\
\text { second } \\
\text { century }\end{array}$ & $\begin{array}{l}\text { Waterlogged cones } \\
\text { (Pinus sp.) }\end{array}$ & Channel & $\begin{array}{l}\text { Maloney and } \\
\text { de Moulins } \\
1990,31\end{array}$ \\
\hline
\end{tabular}




\begin{tabular}{|c|c|c|c|c|c|c|}
\hline Doncaster & Waterdale & Funerary site & $\begin{array}{l}\text { A.D. 70- } \\
200\end{array}$ & $\begin{array}{l}\text { Charred nut shells, } \\
\text { including kernel }\end{array}$ & $\begin{array}{l}\text { Cremation } \\
\text { burials }\end{array}$ & Miller 2013 \\
\hline Finsbury Circus & London & Cemetery & $\begin{array}{l}\text { Second } \\
\text { century }\end{array}$ & $\begin{array}{l}\text { Waterlogged nut } \\
\text { shell }\end{array}$ & $\begin{array}{l}\text { Roadside ditch, } \\
\text { near to } \\
\text { cemetery }\end{array}$ & Davis 2015 \\
\hline Fullerton & Hampshire & Villa & $\begin{array}{l}\text { Early fifth } \\
\text { century }\end{array}$ & $\begin{array}{l}\text { Charred nut shell } \\
\text { fragments }\end{array}$ & $\begin{array}{l}\text { Tiled hearth } \\
\text { within central } \\
\text { hall of Late } \\
\text { Roman villa }\end{array}$ & Campbell 2008 \\
\hline $\begin{array}{l}\text { General } \\
\text { Accident Site }\end{array}$ & York & Major Town & $\begin{array}{l}\text { A.D. } 150- \\
200\end{array}$ & $\begin{array}{l}\text { Waterlogged nut } \\
\text { shells }\end{array}$ & $\begin{array}{l}\text { Accumulation } \\
\text { deposits }\end{array}$ & $\begin{array}{l}\text { Hall and } \\
\text { Kenward, } 1990\end{array}$ \\
\hline $\begin{array}{l}\text { Great Holts } \\
\text { Farm }\end{array}$ & Boreham & Villa & $\begin{array}{l}\text { Third } \\
\text { century }\end{array}$ & $\begin{array}{l}\text { Waterlogged nuts } \\
\text { and bracts }\end{array}$ & Well fill & $\begin{array}{l}\text { Murphy et al. } \\
2000\end{array}$ \\
\hline $\begin{array}{l}\text { Guildhall } \\
\text { Amphitheatre }\end{array}$ & London & Major Town & $\begin{array}{l}\text { A.D. 125- } \\
\text { late } \\
\text { second } \\
\text { century }\end{array}$ & $\begin{array}{l}\text { P. pinea cones and } \\
\text { Pinus sp. branches }\end{array}$ & $\begin{array}{l}\text { Ditch fill and } \\
\text { fence along } \\
\text { ditch }\end{array}$ & $\begin{array}{l}\text { Goodburn } \\
\text { 1999; Bateman } \\
\text { et al. } 2008\end{array}$ \\
\hline Head St & Colchester & Major Town & $\begin{array}{l}\text { A.D. } 70- \\
\text { late } \\
\text { second } \\
\text { century }\end{array}$ & $\begin{array}{l}\text { Charred kernel } \\
\text { fragments }\end{array}$ & Pit & Fryer 2004 \\
\hline Horcott Quarry & $\begin{array}{l}\text { Upper Thames } \\
\text { Valley }\end{array}$ & Funerary site & $\begin{array}{l}\text { A.D. } 100- \\
350\end{array}$ & Charred nut shell & $\begin{array}{l}\text { Cremation } \\
\text { burial }\end{array}$ & $\begin{array}{l}\text { Lodwick and } \\
\text { Challinor } \\
\text { forthcoming }\end{array}$ \\
\hline Low Ham Villa & Somerset & Villa & Roman & $\begin{array}{l}\text { Two waterlogged } \\
\text { cones }\end{array}$ & - & $\begin{array}{l}\text { Rahtz and } \\
\text { Greenfield } \\
1977,365\end{array}$ \\
\hline $\begin{array}{l}\text { Lower Brook } \\
\text { Street }\end{array}$ & Winchester & Major Town & $\begin{array}{l}\text { Second } \\
\text { century }\end{array}$ & Cone & $\begin{array}{l}\text { Pit associated } \\
\text { with Romano- } \\
\text { Celtic temple }\end{array}$ & Ross 1975 \\
\hline $\begin{array}{l}\text { Lullingstone } \\
\text { Villa }\end{array}$ & Kent & Villa & $\begin{array}{l}\text { Late 2nd } \\
\text { century }\end{array}$ & $\begin{array}{l}\text { Waterlogged nuts } \\
\text { and bracts }\end{array}$ & Well & Doherty 1987 \\
\hline $\begin{array}{l}\text { Monkton- } \\
\text { Mount Pleasant }\end{array}$ & Isle of Thanet & $\begin{array}{l}\text { Nucleated } \\
\text { settlement }\end{array}$ & $\begin{array}{l}\text { A.D. } 150- \\
250\end{array}$ & Charred nut shells & $\begin{array}{l}\text { Pits associated } \\
\text { with roadside } \\
\text { settlement }\end{array}$ & Pelling 2008 \\
\hline $\begin{array}{l}\text { Mucking, } \\
\text { Romano-British } \\
\text { Cemetery II }\end{array}$ & Essex & Funerary site & $\begin{array}{l}\text { Later } \\
\text { second } \\
\text { century }\end{array}$ & $\begin{array}{l}\text { Charred pine } \\
\text { kernels and nut shell } \\
\text { fragments }\end{array}$ & $\begin{array}{l}\text { Cremation } \\
\text { burial } 911, \\
\text { epula deposit } \\
\text { of } 10 \text { place } \\
\text { settings }\end{array}$ & $\begin{array}{l}\text { Evans and } \\
\text { Lucy } 2008\end{array}$ \\
\hline $\begin{array}{l}\text { New Royal } \\
\text { Exchange }\end{array}$ & London & Major Town & Roman & Fir cone & Gravel pit & Tite 1848 \\
\hline $\begin{array}{l}\text { New Fresh } \\
\text { Wharf }\end{array}$ & London & Major Town & $\begin{array}{l}\text { First and } \\
\text { second } \\
\text { centuries, } \\
\text { late } \\
\text { second } \\
\text { and third, } \\
\text { third and } \\
\text { fourth. }\end{array}$ & - & $\begin{array}{l}\text { Waterfront } \\
\text { deposits }\end{array}$ & Willcox 1977 \\
\hline Newman's End & North-west Essex & Field system & $\begin{array}{l}\text { Fourth } \\
\text { century }\end{array}$ & $\begin{array}{l}\text { Charred nut shell } \\
\text { fragment }\end{array}$ & Field system & $\begin{array}{l}\text { Carruthers } \\
2000\end{array}$ \\
\hline Orton's Pasture & Rocester & Fort annex & $\begin{array}{l}\text { Early } \\
\text { second } \\
\text { century }\end{array}$ & $\begin{array}{l}\text { Charred nuts, nut } \\
\text { fragments, kernels, } \\
\text { bracts and cone } \\
\text { apex }\end{array}$ & $\begin{array}{l}\text { Pit within } \\
\text { enclosure, } \\
\text { possible shrine }\end{array}$ & Monckton 2000 \\
\hline Prestatyn & North Wales & $\begin{array}{l}\text { Industrial } \\
\text { settlement }\end{array}$ & $\begin{array}{l}\text { Mid- to } \\
\text { late } \\
\text { second } \\
\text { century }\end{array}$ & $\begin{array}{l}\text { Waterlogged intact } \\
\text { cone, nuts and } \\
\text { bracts }\end{array}$ & Well & Jones 1989 \\
\hline Regis House & London & Major Town & Roman & $\begin{array}{l}\text { Waterlogged nut } \\
\text { fragments and bract }\end{array}$ & Near quayside & $\begin{array}{l}\text { Bateman et al. } \\
2008,115\end{array}$ \\
\hline $\begin{array}{l}\text { Roman riverside } \\
\text { wall }\end{array}$ & London & Major Town & $\begin{array}{l}\text { Third } \\
\text { century }\end{array}$ & - & Layer & Willcox 1977 \\
\hline
\end{tabular}




\begin{tabular}{|l|l|l|l|l|l|l|}
\hline $\begin{array}{l}\text { Springhead, } \\
1994 \text { pipeline }\end{array}$ & Northfleet, Kent & $\begin{array}{l}\text { Roadside } \\
\text { settlement }\end{array}$ & $\begin{array}{l}\text { Mid-later } \\
\text { second } \\
\text { century }\end{array}$ & $\begin{array}{l}\text { Charred nut shell } \\
\text { fragments }\end{array}$ & $\begin{array}{l}\text { Occupation } \\
\text { overlying } \\
\text { hearth within } \\
\text { building }\end{array}$ & Campbell 1999 \\
\hline $\begin{array}{l}\text { Springhead, } \\
\text { sanctuary } \\
\text { complex }\end{array}$ & Northfleet, Kent & Religious & $\begin{array}{l}\text { Early- } \\
\text { mid- } \\
\text { Roman }\end{array}$ & $\begin{array}{l}\text { Charred bracts and } \\
\text { nutshell }\end{array}$ & $\begin{array}{l}\text { Spring infill in } \\
\text { front of shrine, } \\
\text { chalk quarries }\end{array}$ & Stevens 2011 \\
\hline $\begin{array}{l}\text { Temple of } \\
\text { Mithras }\end{array}$ & London & Major Town & $\begin{array}{l}\text { First- } \\
\text { second } \\
\text { century }\end{array}$ & $\begin{array}{l}\text { Pine cone (type not } \\
\text { specified) }\end{array}$ & $\begin{array}{l}\text { Floor of nave } \\
\text { of Mithraeum }\end{array}$ & $\begin{array}{l}\text { Grimes 1968, } \\
114\end{array}$ \\
\hline $\begin{array}{l}\text { Triangular } \\
\text { Temple, Insula } \\
\text { VII }\end{array}$ & Verulamium & Major Town & $\begin{array}{l}\text { Early } \\
\text { second } \\
\text { century }\end{array}$ & $\begin{array}{l}\text { Charred bracts and } \\
\text { kernels }\end{array}$ & Pits within pits & $\begin{array}{l}\text { Wheeler and } \\
\text { Wheeler 1936 }\end{array}$ \\
\hline $\begin{array}{l}\text { Upper Thames } \\
\text { St }\end{array}$ & London & Major Town & $\begin{array}{l}\text { Early third } \\
\text { century }\end{array}$ & Waterlogged bract & $\begin{array}{l}\text { Dumped } \\
\text { riverside } \\
\text { deposit }\end{array}$ & Willcox 1980 \\
\hline Westhawk Farm & Ashford, Kent & $\begin{array}{l}\text { Roadside } \\
\text { settlement }\end{array}$ & $\begin{array}{l}\text { A.D. 70- } \\
150\end{array}$ & Charred nut shell & $\begin{array}{l}\text { Central pit of } \\
\text { shrine structure }\end{array}$ & Pelling 2008 \\
\hline
\end{tabular}

\section{BIBLIOGRAPHY}

Alcock, J.P. 1980: 'Classical religious belief and burial practice in Roman Britain', Archaeological Journal 137, 50-85

Aldhouse-Green, M.J. 2004: An Archaeology of Images: Iconology and Cosmology in Iron Age and Roman Europe, London

Allen, M., Blick, N., Brindle, T., Evans, T., Fulford, M., Holbrook, N., and Smith, A. 2015: The Rural Settlement of Roman Britain: an Online Resource [data-set]. Archaeology Data Service [distributor], York (doi: 10.5284/1030449)

Allevato, E., Russo Ermolli, E., Boetto, G., and Di Pasquale, G. 2010: 'Pollen-wood analysis at the Neapolis harbour site (1st-3rd century AD, southern Italy) and its archaeobotanical implications', Journal of Archaeological Science 37 (9), 2365-75

Allison, J. 1947: 'Buxus sempervirens in a Late Roman burial in Berkshire: data for the study of post-glacial history of British vegetation. XI', New Phytologist 46 (1), 122

Applebaum, S. 1958: 'Agriculture in Roman Britain', Agricultural History Review 6 (2), 66-86

Bakels, C., and Jacomet, S. 2003: 'Access to luxury foods in Central Europe during the Roman period: the archaeobotanical evidence', World Archaeology 34 (3), 542-57

Barnett, C. 2011: 'Wood charcoal', in Barnett et al. 2011, 113-19

Barnett, C., McKilney, J., Stafford, E., Grimm, J., and Stevens, C. 2011: Settling the Ebbsfleet Valley. High Speed 1 Excavations at Springhead and Northfleet, Kent. The Late Iron Age, Roman, 
Saxon, and Medieval Landscape. Volume 3: Late Iron Age to Roman Human Remains and Environmental Reports, Oxford

Bartley, D.D., and Morgan, A.V. 1990: 'The palynological record of the King's Pool, Stafford, England', New Phytologist 116, 177-94

Batchelor, C.R., Allott, L., Elias, S., Campbell, G., Branch, N.P., Green, C.P., Marini, N., Austin, P., Giorgi, J., and Jones, L. 2011: Drapers Gardens, 12 Throgmorton Avenue, City of London: Environmental Archaeological Analysis (Site Code: DGT06), Quaternary Scientific (QUEST), unpub. Report October 2011, Project Number 037/08

Bateman, N., Cowan, C., and Wroe-Brown, R. 2008: London's Roman Amphitheatre: Guildhall Yard, City of London, MoLAS Monograph 35, London

Bennett, K.D. 1984: 'The post-glacial history of Pinus sylvestris in the British Isles', Quaternary Science Reviews 3, 133-55

Bernal, M., Llorens, L., and Julkunen-Titto 2013: 'Altitudinal and seasonal changes of phenolic compounds in Buxus sempervirens leaves and cuticles', Plant Physiology and Biochemistry 70, $471-82$

Berti, F. 1990: Fortuna Maris: la Nave Romana di Comacchio, Bologna

Betts, E. 2011: 'Towards a multisensory experience of movement in the city of Rome', in Laurence and Newsome 2011, 118-32

Biddle, M., and Quirk, R.N. 1964: 'Excavations near Winchester Cathedral, 1961', Archaeological Journal 119, 150-94

Bird, J. 2004: 'Incense in Mithraic ritual: the evidence of the finds', in M. Martens and G. De Boe (eds), Roman Mithraism, the Evidence of the Small Finds, Brussels, 191-9

Blackburn, K. 1951: 'Appendix I. Report upon the natural pine-cones from the Temple of Mithras at Carrawburgh', in Richmond and Gillam 1951, 86

Blagg, T.F.C. 2000: 'Sculptures and architectural fragments', in MacKinder 2000, 61-3

Boivin, N., Fuller, D.Q., and Crowther, A. 2012: 'Old World globalization and the Columbian exchange: comparison and contrast', World Archaeology 44 (3), 452-69 
Booth, P., Dodd, A., Robinson, M., and Smith, A. 2007: The Thames through Time: the Archaeology of the Gravel Terraces of the Upper and Middle Thames: the Early Historical Period, AD 1-1000, Thames Valley Landscape Monograph 27, Oxford

Borchard, F., Berger, H.-J., Bunzel-Drüke, M., and Fartmann, T. 2011: 'Diversity of plant-animal interactions: possibilities for a new plant defense indicator value?', Ecological Indicators 11, $1311-18$

Bosi, G., Maria Mercuri, A., Bandini Mazzanti, M., Florenzano, A., Chiara Montecchi, M., Torri, P., Labate, D., Rinaldi, R. 2015: 'The evolution of Roman urban environments through the archaeobotanical remains in Modena - Northern Italy', Journal of Archaeological Science 53, 1931

Bouby, L., and Marinval, P. 2004: 'Fruits and seeds from Roman cremations in Limagne (Massif Central) and the spatial variability of plant offerings in France', Journal of Archaeological Science $31,77-86$

Bradley, M. 2015a: 'Introduction: smell and the ancient senses', in Bradley 2015b, 1-16

Bradley, M. (ed.) 2015b: Smell and the Ancient Senses, London

Braimbridge, M.V. 2008: 'Boxwood in Roman times', Topiarius 12 http://www.ebts.org/2013/12/boxwood-in-roman-times-by-mark-v-braimbridge/ (Accessed $7 / 6 / 2016)$

Brettell, R.C., Schotsmans, E.M.J., Walton Rogers, P., Reifarth, N., Redfern, R.C., Stern, B., and Heron, C.P. 2015: “"Choicest unguents”: molecular evidence for the use of resinous plant exudates in late Roman mortuary rites in Britain', Journal of Archaeological Science 53, 639-48

Brice, J. 2014: 'Attending to grape vines: perceptual practices, planty agencies and multiple temporalities in Australian viticulture', Social \& Cultural Geography 15, 942-65

Brown, A.E. (ed.) 1991: Garden Archaeology, Papers Presented to a Conference at Knutston Hall, Northamptonshire, April 1988, CBA Research Report 78, London

Busby, P., de Moulins, D., Lyne, M., McPhillips, S., and Scaife, R. 2001: 'Excavations at Clatterford Roman villa, Isle of Wight', Proceedings of the Hampshire Field Club and Archaeology Society 56, 95-128 
Butler, J. and Ridgeway, V. 2009: Secrets of the Gardens: Archaeologists Unearth the Lives of Roman Londoners at Drapers' Gardens, Pre-Construct Archaeology, Brockley

Campbell, G. 1999: 'The charred plant remains', in A. Boyle and R. Early, Excavations at Springhead Roman Town, Southfleet, Kent, OAU Occasional Paper 1, Oxford, 36-9

Campbell, G. 2008: 'Charred plant remains', in B. Cunliffe, The Danebury Environs Roman Programme: a Wessex Landscape During the Roman Era Volume 2 pt. 3. Fullerton, Hants, 2000 and 2001, English Heritage and Oxford University School of Archaeology, Oxford, 161-4

Campbell, G. 1995: 'Waterlogged plant remains', in R. Perrin, Raunds Iron Age and Romano-British Project: Assessment Report, November 1995, English Heritage Central Archaeology Service

Caneva, G., and Bohuny, L. 2003: ‘Botanic analysis of Livia's villa painted flora (Prima Porta, Roma)', Journal of Cultural Heritage 4 (2), 149-55

Carrott, J., Dobney, K., Hall, A., Kenward, H., and Miles, A. 1992: An Evaluation of Environmental Evidence from Excavations at 50 Piccadilly, York (YAT/Yorkshire Museum site code: 1992.10), Environmental Archaeology Unit, York

Carruthers, W. 2000: 'Charred plant remains', in E. Guttmann: 'Excavations on the Hatfield Heath to Matching Tye rising main, north-west Essex', Essex Archaeology and History 31, 27-9

Chadwick, A.M. 2015: 'Doorways, ditches and dead dogs - material manifestations of practical magic in Iron Age and Roman Britain', in C. Houlbrook and N. Armitage (eds), The Materiality of Magic: an Artefactual Investigation into Ritual Practices and Popular Beliefs, Oxford, 37-64

Challinor, D. 2008: 'Wood charcoal', in P. Bennett, P. Clark, A. Hicks, J. Rady and I. Riddler, At the Great Crossroads: Prehistoric, Roman and Medieval Discoveries on the Isle of Thanet 1994-95, Canterbury, 343-9

Coates, R. 1999: 'Box in English place names', English Studies 80 (1), 2-45

Columella: On Agriculture, Volume III: Books 10-12. On Trees. Translated by E.S. Forster, E.H. Heffner. Loeb Classical Library 408. Cambridge, MA: Harvard University Press, 1955

Cowan, C., and Hinton, P. 2008: 'The Roman garden in London', in J. Clark, J. Cotton, J. Hall, R. Sherris and H. Swain (eds), Londinium and Beyond: Essays on Roman London and its Hinterland for Harvey Sheldon, CBA Research Report 156, York, 75-81 
Crosby, V., and Muldowney, L. 2011: Stanwick Quarry, Northamptonshire. Raunds Area Project: Phasing the Iron Age and Romano-British Settlement at Stanwick, Northamptonshire (Excavations 1984-1992). Archaeological Report: Volume 2, English Heritage Research Department Report Series 54-2011

Crummy, N. 2010: 'Bears and coins: the iconography of protection in Late Roman infant burials', Britannia 41, 37-93

Cunliffe, B. 1981: 'Roman gardens in Britain: a review of the evidence', in MacDougall and Jashemski 1981, 95-108

Dalton, O.M. 1920: 'A sculptured marble slab from northern Mesopotamia', Proceedings of the Society of Antiquaries of London 32, 54-62

Daly, L., French, K., Miller, T.L., and Nic Eoin, L. 2016: 'Integrating ontology into ethnobotanical research', Journal of Ethnobiology 36 (1), 1-9

Davenport, P., Poole, C., and Jordan, D. 2007: Archaeology in Bath: Excavations at the New Royal Baths (the Spa), and Bellott's Hospital 1998-1999, Oxford Monograph 1, Oxford

Davis, A. 2011: 'Botanical remains', in J. Hill and P. Rowsome, Roman London and the Walbrook Stream Crossing: Excavations at 1 Poultry and Vicinity, City of London Part II, MoLA Monograph 37, London, 524-33

Davis, A. 2015: 'The plant remains', in C. Harward, N. Powers and S. Watson, The Upper Walbrook Valley Cemetery of Roman London: Excavations at Finsbury Circus, City of London, 1987-2007, MOLA Monograph 69, London, 169-75

Decocq, G., Bordier, D., Wattez, J.-R., and Racinet, P. 2004: ‘A practical approach to assess the native status of a rare plant species: the controverse of Buxus sempervirens L. in northern France revisited', Plant Ecology 173 (1), 139-51

Di Domenico, F., Lucchese, F., and Magri, D. 2011: 'Late glacial and Holocene history of Buxus sempervirens L. in Italy', Annali Di Botanica 1, 45-58

Di Domenico, F., Lucchese, F., and Magri, D. 2012: 'Buxus in Europe: late quaternary dynamics and modern vulnerability', Perspectives in Plant Ecology, Evolution and Systematics 14 (5), 354-62 
Dickson, C. 1994: 'Macroscopic fossils of garden plants from British Roman and Medieval deposits, in D. Moe, J. Dickson and P.M. Jorgensen (eds), Garden History: Garden Plants, Species, Forms and Varieties from Pompeii to 1800, Rixensart, 47-72

Dimbleby, G. 1978: Plants and Archaeology, London

Doherty, G. 1987: 'The pine-scales', in G. Meates, The Roman Villa at Lullingstone, Kent. Volume II: the Wall Paintings and Finds, Kent Archaeological Society Monograph 3, Maidstone, 318

Dorcey, P. 1992: The Cult of Silvanus: A Study in Roman Folk Religion, Columbia Studies Classical Tradition 20, Leiden/New York

Draycott, H. 2015: 'Smelling trees, flowers and herbs in the Ancient world', in Bradley 2015b, 60-73

Eckardt, H. 2014: Objects and Identities: Roman Britain and the North-Western Provinces, Oxford

Eckardt, H., Brewer, P., Hay, S., and Poppy, S. 2009: 'Roman barrows and their landscape context: a GIS case study at Bartlow, Cambridgeshire', Britannia 40, 65-98

Elsner, J. 2012: 'Sacrifice in late Roman art', C.A. Faraone and F.S. Naiden (eds), Greek and Roman Animal Sacrifice: Ancient Victims, Modern Observers, Cambridge

Evans, C., and Lucy, S. 2008: Mucking Excavations, Essex. Archive and Publication Project Prehistoric and Roman - Overview and Assessment, Cambridge Archaeological Unit, Cambridge (doi: 10.5284/1000060)

Farrar, L. 2011: Ancient Roman Gardens, Stroud

Fitter, A.H., and Peat, H. 1994: 'The ecological flora database', Journal of Ecology 82, 415-25, http://www.ecoflora.co.uk/index.php (Accessed 17/4/2016)

Fless, F. 1995: Opferdiener und Kultmusiker auf Stadtrömischen Historichen Reliefs, Mainz

Fryer, V. 2004: 'Charred plant macrofossils and other remains', in H. Brooks, Archaeological Excavation at 29-39 Head Street, Colchester, Essex May-September 2000, Colchester, 169-85

Fryer, V., and Murphy, P. 2014: 'Plant macrofossils', in T. Ashwin and A. Tester, A Romano-British Settlement in the Waveney Valley: Excavations at Scole 1993-4, Norfolk Historic Environment Service in conjunction with NPS Archaeology, Suffolk County Council Archaeological Service and ALGAO East, Dereham, 400-2

Fulford, M., and Holbrook, N. 2011: 'Assessing the contribution of commercial archaeology to the study of the Roman period in England, 1990-2004', Antiquaries Journal 91, 323-45 
Gage, J. 1839: ‘A letter from John Gage, Esq. F.R.S., Director, to Hudson Gurney, Esq. F.R.S. V.P. \&c. containing an account of further discoveries of Roman sepulchral relics at the Bartlow Hills', Archaeologia 28 (1), 1-6

Gaitzsch, W., Knörzer, K.-H., Köhler, R., Kokabi, M., Meurers-Balke, J., Neyses, M., and Radermacher, H. 1989: ‘Archäologische und naturwissenschaftliche Beiträge zu einem römischen Brunnensediment aus der rheinischen Lössbörde’, Bonner Jahrbücher 189, 225-83

Giesecke, T., and Bennett, K. D. 2004: 'The Holocene spread of Picea abies (L.) Karst. in Fennoscandia and adjacent areas', Journal of Biogeography 31, 1523-48

Giorgi, J. 1997: 'The plant remains', in Mackinder 2000, 65-6

Girard, M., and Tchernia, A. 1978: 'Remarques a propos des cones de pin pignon (Pinus pinea) decouverts sur l'epave de la madrauge de Giens', in A. Tchernia, P. Pompey and A. Hesnard, L'Épave Romaine de la Madrague de Giens (Var), Campagnes 1972-1975: Fouilles de l'Institut d'Archéologie Méditerranéenne, Éditions du Centre National de la Recherche Scientifique, Paris, $117-18$

Gleason, K.L. 1994: 'Porticus Pompeiana: a new perspective on the first public park of ancient Rome', Journal of Garden History 14 (1), 13-27

Gleason, K.L. 2010: 'Constructing nature: the built garden. With notice of a new monumental garden at the Villa Arianna, Stabiae', in International Congress of Classical Archaeology Meetings Between Cultures in the Ancient Mediterranean, Bolletino di Archeologia on line, Volume Speciale, $8-15$

Godwin, H. 1975: The History of the British Flora, Cambridge

Goodburn, D. 1999: 'The evidence for the introduction of the Mediterranean "Stone Pine" to Roman England', NewsWARP 25, 19-22

Gosden, C., and Marshall, Y. 1999: 'The cultural biography of objects', World Archaeology 31 (2), $169-78$

Gray, H.S.G. 1918: 'Leaden coffin found at Cann, near Shaftesbury', Proceedings of the Dorset Natural History and Antiquarian Field Club 38, 68-73

Green, M.J. 1976: The Religions of Civilian Roman Britain, BAR British Series 24, Oxford

Grimes, W. 1968: The Excavation of Roman and Mediaeval London, London 
Hall, A.R., and Kenward, H.K. 1990: Environmental Evidence from the Colonia: Tanner Row and Rougier Street, Archaeology of York 14/6, York

Hall, A.R., Kenward, H.K., and Williams, D. 1980: Environmental Evidence from Roman Deposits in Skeldergate, Archaeology of York 14/3, York

Hall, M. 2011: Plants as Persons: a Philosophical Botany, Albany

Hamilakis, Y. 2011: 'Archaeology of the senses', in T. Insoll (ed.), Oxford Handbook of the Archaeology of Ritual and Religion, Oxford, 208-25

Head, L., and Atchison, J. 2009: 'Cultural ecology: emerging human-plant geographies', Progress in Human Geography 33 (2), 236-45

Head, L., Atchison, J., Phillips, C., and Buckingham, K. 2014: 'Vegetal politics: belonging, practices and places', Social and Cultural Geography 15 (8), 861-70

Henig, M. 1984: Religion in Roman Britain, London

Henricot, B., and Culham, A. 2002: 'Cylindrocladium buxicola, a new species affecting Buxus spp., and its phylogenetic status', Mycologia 94 (6), 980-97

Henshaw, V. 2014: Urban Smellscapes - Understanding and Designing City Smell Environments, London

Hicks, D. 2010: 'The material-cultural turn: event and effect', in D. Hicks and M. C. Beaudry (eds), The Oxford Handbook of Material Culture Studies, Oxford, 25-99

Hill, J., and Rowsome, P. 2011: Roman London and the Walbrook Stream Crossing: Excavations at 1 Poultry and Vicinity, City of London, London

Hill, M.O., Preston, C.D., and Roy, D.B. 2004: PLANTATT. Attributes of British and Irish Plants:

Status, Size, Life History, Geography and Habitats, Centre for Ecology \& Hydrology, Huntingdon

Hitchings, R. 2003: 'People, plants and performance: on actor network theory and the material pleasures of the private garden', Social and Cultural Geography 4 (1), 99-114

Hood, S., and Walton, H. 1948: ‘A Romano-British cremating place and burial ground on Roden Downs, Compton, Berkshire', Transactions of the Newbury and District Field Club 9 (1), 10-62 Hughes, J.D. 2003: 'Europe as consumer of exotic biodiversity: Greek and Roman times', Landscape Research 28 (1), 21-31 
Ingold, T. 1993: 'The temporality of the landscape', World Archaeology 35 (2), 152-74

Jackson, R.P.J., and Potter, T.W. 1996: Excavations at Stonea, Cambridgeshire 1980-85, London

Jashemski, W.F. 1981: 'The Campanian peristyle garden', in Macdougall and Jashemski 1981, 31-48

Jashemski, W.F., Foss, J.E., Lewis, R.J., Timpson, M.E., and Lee, S.Y. 1995: 'Roman gardens in Tunisia: preliminary excavations in the House of Bacchus and Ariadne and in the East Temple at Thuburbo Maius', American Journal of Archaeology 99 (4), 559-76

Jones, J. 1989: 'Botanical remains', in K. Blockley, Prestatyn 1984-5: An Iron Age Farmstead and Romano-British Industrial Settlement in North Wales, BAR British Series 210, Oxford, 171-9

Jones, O., and Cloke, P. 2008: 'Non-human agencies: trees in place and time', in C. Knappett and L. Malafouris (eds), Material Agency: Towards a Non-anthropocentric Approach, Dusseldorf, 79-96

Kefalidou, E. 2009: 'The plants of victory in ancient Greece and Rome', in J.-P. Morel and A.M. Mercuri (eds), Plants and Culture: Seeds of the Cultural Heritage of Europe, Bari, 39-44

Kenward, H.K., Addyman, P.V, Hall, A.R., and Jones, A.K.G. 1986: Environmental Evidence from a Roman Well and Anglian Pits in the Legionary Fortress. Archaeology of York 14/5, York

Kislev, M. 1988: 'Pinus pinea in agriculture, culture and cult', in H. Kuster (ed.), Der Prähistorische Mensch und seine Umwelt. Fetschrift für Udelgard Körber Grohne zum 65 Geburtstag, Stuttgart, 73-9

Knörzer, K.-L., and Neu, S. 1998: ‘Archäologische untersuchungen an der plectrudengasse in Köln', Kölner Jahrbuch 31, 445-80

Koloski-Ostrow, A.O. 2015: 'Roman urban smells: the archaeological evidence', in Bradley 2015b, 90-109

Kopytopff, I. 1986: 'The cultural biography of things: commoditization as process', in A. Appadurai (ed.), The Social Life of Things: Commodities in Cultural Perspectives, Cambridge, 64-91

Lamboglia, N. 1952: 'La nave Romana die Albenga', Rivista Di Studi Liguri 18 (3/4), 131-236

Lambrick, G., and Robinson, M. 1979: Iron Age and Roman Riverside Settlements at Farmoor, Oxford, CBA Research Report 32, London

Laurence, R., and Newsome, D. (eds) 2011: Rome, Ostia, Pompeii: Movement and Space, Oxford Livarda, A. 2013: 'Date, rituals and socio-cultural identity in the north-western Roman provinces', Oxford Journal of Archaeology 32, 101-17 
Lodwick, L. 2015: 'Identifying ritual deposition of plant remains: a case study of stone pine cones in Roman Britain', in T. Brindle, M. Allen, E. Durham and A. Smith (eds), TRAC 2014: Proceedings of the Twenty-Fourth Annual Theoretical Roman Archaeology Conference, Oxford, 54-69

Lodwick, L.A. 2016: “"The debatable territory where geology and archaeology meet”: reassessing the early archaeobotanical work of Clement Reid and Arthur Lyell at Roman Silchester', Environmental Archaeology (doi: 10.1080/14614103.2015.1116218)

Lodwick, L., and Challinor, D. forthcoming: 'The plant remains from cremations 3343 and 4593', in Horcott Quarry, Oxford Archaeology

Mabey, R. 1996: Flora Britannica: The Definitive New Guide to Wild Flowers, Plants and Trees, London

Macaulay-Lewis, E. 2008: 'The fruits of victory: generals, plants and power in the Roman World', in E. Bragg, L. Hay and E. Macaulay-Lewis (eds), Beyond the Battlefields: New Perspectives on Warfare and Society in the Graeco-Roman World, Newcastle upon Tyne, 205-25

Macaulay-Lewis, E. 2011: 'The city in motion: walking for transport and leisure in the city of Rome', in Laurence and Newsome 2011, 262-89

Macchioni, F., Cioni, P.L., Flamini, G., Morelli, I., Maccioni, S., and Ansaldi, M. 2003: 'Chemical composition of essential oils from needles, branches and cones of Pinus pinea, P. halepensis, P. pinaster and P. nigra from central Italy', Flavour and Fragrance Journal 18, 139-43

Macdougall, E.B. and Jashemski, W.F. 1981: Ancient Roman Gardens, Washington

MacKinder, A. 2000: A Romano British Cemetery on Watling Street. Excavations at 165 Great Dover Street, Southwark, London, MoLAS Archaeology Studies Series 4, London

Mally, R., and Nuss, M. 2010: 'Phylogeny and nomenclature of the box tree moth, Cydalima perspectalis (Walker, 1859) comb. n., which was recently introduced into Europe (Lepidoptera: Pyraloidea: Crambidae: Spilomelinae)', European Journal of Entomology 107 (3), 393-400

Maloney, C., and de Moulins, D. 1990: The Upper Walbrook Valley in the Roman Period, CBA Research Report 69, London

Marinval, P., Maréchal, D., and Labadie, D. 2002: ‘Arbres fruitiers et cultures jardinées galloromains à Longueil-Sainte-Marie (Oise)', Gallia 59 (1), 253-71 
Marzano, A. 2014: 'Roman gardens, military conquests, and elite self-representation', in K. Coleman (ed.), Le Jardin dans l'Antiquité. Entretiens sur l'Antiquité Classique (LX), Geneva, 195-244

Mercuri, A.M., Accorsi, C.A., Bandini Mazzanti, M., Bosi, G., Terranova, F., Torri, P., Trevisan Grandi, G., Montecchi, M.C., and Olmi, L. 2006: 'The Greek-Roman theatre of Taormina: pollen and microanthracological data for the proposal of a "Historical Green Park", in J.P. Morel, J. Tresserras and J.C. Matalama (eds), The Archaeology of Crop Fields and Gardens, Bari, 161-74

Meurers-Balke, J., and Herchenbach, M. 2014: 'Römische gartenkunst am Niederrhein', Archäologie im Rheinland 2014, 151-4

Miller, H., Carden, R.F., Evans, J., Lamb, A., Madgwick, R., Osborne, D., Symmons, R., and Sykes, N. 2016: 'Dead or alive? Investigating long-distance transport of live fallow deer and their body parts in antiquity', Environmental Archaeology 21 (3), 246-59

Miller, J. 2013: 'Appendix 18 - Botanical analysis of cremation deposits', in G. Davies, Excavations at Waterdale, Doncaster. Excavation Report, ArcHeritage Report 2013/13.3, Sheffield (doi: $10.5284 / 1029314,117-24)$

Monckton, A. 2000: 'Charred plant remains', in I. Ferris, L. Bevan, and R. Cuttler (eds), The Excavation of a Romano-British Shrine at Orton's Pasture, Rocester, Staffordshire, BAR British Series 314, Oxford, 67-71

Moser, D., Allevato, E., Clarke, J.R., Di Pasquale, G., and Nelle, O. 2012: 'Archaeobotany at Oplontis: woody remains from the Roman Villa of Poppaea (Naples, Italy)', Vegetation History and Archaeobotany 22 (5), 397-408

Murphy, C., Thompson, G., and Fuller, D.Q. 2013: 'Roman food refuse: urban archaeobotany in Pompeii, Regio VI, Insula 1', Vegetation History and Archaeobotany 22 (5), 409-19

Murphy, P. 1977: Early Agriculture and Environment on the Hampshire Chalklands: circa. 800 B.C. -400 A.D., unpub. MPhil thesis, University of Southampton

Murphy, P. 1984: 'Environmental archaeology in East Anglia', in H.C.M. Keeley (ed.), Environmental Archaeology: A Regional Review, London, 13-42

Murphy, P. 1998: A Review of Plant Macrofossils from Archaeological Sites in the Eastern Counties, Norwich 
Murphy, P. 2001: Review of Wood and Macroscopic Wood Charcoal from Archaeological Sites in the West and East Midlands Regions and the East of England, Centre for Archaeology Report 23/2001, Portsmouth

Murphy, P., and Scaife, R. 1991: 'The environmental archaeology of gardens', in Brown 1991, 83-99

Murphy, P., Albarella, U., and Germany, M. 2000: 'Production, imports and status: biological remains from a Late Roman farm at Great Holts Farm, Essex, UK', Environmental Archaeology 5, $35-48$

Mutke, S., Calama, R., Gonzalez-Martinez, S., Montero, G., Gordo, F., Bono, D., and Gil, L. 2012: 'Mediterranean stone pine: botany and horticulture', Horticultural Reviews 39, 153-201

Nealon, J.T. 2016: Plant Theory: Biopower \& Vegetable Life, Stanford

Oldfield, F., and Statham, D.C. 1963: 'Pollen analytical data from Urswick Tarn and Ellerside Moss, N. Lancashire', New Phytologist 62, 53-66

Overbeck, J., and Mau, A. 1884: Pompeji in seinen Gebäuden, Alterthümern und Kunstwerken, Leipzig

Pearson, E., and Robinson, M. 1994: 'Environmental evidence from the villa', in R.J. Williams and E.J. Zeepvat, Bancroft: A Late Bronze Age/Iron Age Settlement Roman Villa \& TempleMausoleum. Volume 2 Finds \& Environmental Evidence, Buckinghamshire Archaeological Society Monograph Series 7, Aylesbury, 565-84

Pellegrini, P., and Baudry, S. 2014: 'Streets as new places to bring together both humans and plants: examples from Paris and Montpellier (France)', Social \& Cultural Geography 15 (8), 871-900

Pelling, R. 2008: ‘The charred plant remains', in P. Bennett, P. Clark, A. Hicks, J. Rady, and I. Riddler, At the Great Crossroads: Prehistoric, Roman and Medieval Discoveries on the Isle of Thanet 1994-95, Canterbury, 262-9

Peterken, G.F. 2001: 'Ecological effects of introduced tree species in Britain', Forest Ecology and Management 141, 31-42

Pigott, C., and Walters, S. 1953: 'Is the Box-tree a native of England?', in J.E. Lousley (ed.), The Changing Flora of Britain, Oxford, 184-7 
Piranomonte, M. 2015: 'The discovery of the fountain of Anna Perenna and its influence on the study of ancient magic', in G. Bąkowska-Czerner, A. Roccati and A. Świerzowska (eds), The Wisdom of Thoth. Magical Texts in Ancient Mediterranean Civilisations, Oxford, 71-85

Pitt, H. 2015: 'On showing and being shown plants - a guide to methods for more-than-human geography', Area 47 (1), 48-55

Pliny the Younger: Letters. Translated by B. Radice. Loeb Classical Library 59. Cambridge, MA: Harvard University Press, 1989

Pliny the Elder: Natural History Volume IV: Books 12-16. Translated by H. Rackham. Loeb Classical Library 370. Cambridge, MA: Harvard University Press, 1945

Pliny the Elder: Natural History Volume V: Books 17-19. Translated by H. Rackham. Loeb Classical Library 371. Cambridge, MA: Harvard University Press, 1950

Pollard, E.A. 2009: 'Pliny's Natural History and the Flavian Templum Pacis: botanical imperialism in first-century C.E. Rome', Journal of World History 20 (3), 309-38

Popova, T. 2010: 'Archaeobotanical data from the ancient town of Apolonia', Anadolu Araştirmalari Jahrbuch Für Kleinasiatische Forschung 19 (1), 213-26

Price, E. 2000: Frocester: A Romano-British Settlement, its Antecedents and Successors. Volume 2: The Finds, Stonehouse

Pugsley, P. 2003: Roman Domestic Wood: Analysis of the Morphology, Manufacture and Use of Selected Categories of Domestic Wooden Artefacts with Particular Reference to the Material from Roman Britain, BAR International Series 1118, Oxford

Ramsay, J. 2010: 'Trade or trash: an examination of the archaeobotanical remains from the Byzantine harbour at Caesarea Maritima, Israel', International Journal of Nautical Archaeology 39 (2), 37682

Rahtz, P., and Greenfield, E. 1977: Excavations at Chew Valley Lake Somerset, London

RIB: The Roman Inscriptions of Britain I, Inscriptions on Stone, R.G. Collingwood and R.P. Wright (eds), Oxford (1965)

Richmond, I.A., and Gillam, J. 1951: 'The temple of Mithras at Carrawburgh', Archaeologia Aeliana 29, 1-92 
Roberts, K. 2008: 'Plant remains', in D. Swift, Roman Waterfront Development at 12 Arthur Street, City of London, MOLAS Archaeology Studies Series 19, London, 67-70

Robinson, M. 2002: 'Domestic burnt offerings and sacrifices at Roman and pre-Roman Pompeii, Italy', Vegetation History and Archaeobotany 11, 93-9

Robinson, M. 2007: 'The environmental archaeology of the Cotswold Water Park', in D. Miles, S. Palmer, A. Smith and G. Edgeley Long, Iron Age and Roman Settlement in the Upper Thames Valley: Excavations at Claydon Pike and Other Sites within the Cotswold Water Park, Thames Valley Landscapes Monograph 26, Oxford, 355-64

Robinson, M. 2011a: 'The macroscopic plant and invertebrate remains', in M. Fulford and A. Clarke, Silchester: City in Transition, Britannia Monograph Series 25, London, 281-93

Robinson, M. 2011b, 'Charred and waterlogged remains', in M. Luke and T. Preece, Farm and Forge: Late Iron Age/Romano-British Farmsteads at Marsh Leys, Kempston, Bedfordshire, East Anglian Archaeology Report 138, Bedford, 128-34

Robinson, M. 2015: 'The place of developer-funded archaeobotany in elucidating the food supply of the towns of Roman Britain', in M. Fulford and N. Holbrook (eds), The Towns of Roman Britain: The Contribution of Commercial Archaeology Since 1990, Britannia Monograph Series 27, London, 167-74

Rosati, L., Masi, A., Giardini, M., and Marignani, M. 2015: 'Under the shadow of a big plane tree: why Platanus orientalis should be considered an archaeophyte in Italy', Plant Biosystems - An International Journal Dealing with All Aspects of Plant Biology 149 (1), 185-94

Ross, A. 1975: 'A wooden statuette from Venta Belgarum' in M. Biddle, 'Excavations at Winchester, 1971: Tenth and Final Interim Report: Part II', Antiquaries Journal 55, 335-6

Rottoli, M., and Castiglioni, E. 2011: 'Plant offerings from Roman cremations in northern Italy: a review', Vegetation History and Archaeobotany 20 (5), 495-506

Scaife, R. 1986: 'Pollen in human palaeofaeces; and a preliminary investigation of the stomach and gut contents of Lindow Man' in I.M. Stead, J.B. Bourke and D. Brothwell, Lindow Man. The Body in the Bog, London, 126-35 
Scaife, R. 2011: 'Pollen analysis of sediments', in J. Hill and P. Rowsome, Roman London and the Walbrook Stream Crossing: Excavations at 1 Poultry and Vicinity, City of London, MoLA Monograph 37, London, 533-9

Sealey, P. 2009: 'New light on the wine trade with Julio-Claudian Britain', Britannia 40, 1-40

Smith, W. 2002: A Review of Archaeological Wood Analyses in Southern England, Centre for Archaeology Report 75/2002, Portsmouth

Smythe, J. 1951: 'Appendix II. Report upon the pine-cone fuel from the Mithraeum at Carrawburgh', in Richmond and Gillam 1951, 86-7

Šoštarić, R., and Küster, H. 2001: 'Roman plant remains from Veli Brijun (island of Brioni), Croatia', Vegetation History and Archaeobotany 10 (4), 227-33

Stace, C. 2010: New Flora of the British Isles, Cambridge

Stant, M.Y., and Metcalfe, C.R. 1977: 'Seeds and other plant debris', in Rahtz and Greenfield 1977, $372-3$

Stevens, C. 2011: 'Charred plant remains from Springhead', in Barnett et al. 2011, 95-105

Sykes, N. 2009: 'Worldviews in transition: the impact of exotic plants and animals on Iron Age/Romano-British landscapes', Landscapes 10 (2), 19-36

Sykes, N. 2014: Beastly Questions: Animal Answers to Archaeological Issues, London

Taylor, A. 1999: Roman Cambridge: Excavations on Castle Hill, 1956-1988, Proceedings of the Cambridge Antiquarian Society 88

Thomas, J. 2015: 'The future of archaeological theory', Antiquity 89, 1287-96

Tillyard, E. 1917: ‘A Cybele altar in London', Journal of Roman Studies 7, 284-88

Tite, W. 1848: A Descriptive Catalogue of the Antiquities found in the Excavations at the New Royal Exchange, Preserved in the Museum of the Corporation of London ... with some Particulars and Suggestions Relating to Roman London, Printed for the use of the members of the Corporation of the City of London, London

Tomlinson, P., and Hall, A. 1996: 'Review of archaeological evidence for food plants from the British Isles (ABCD)', Internet Archaeology 1 (doi: 10:11141/ia.1.5)

Totelin, L. 2012: 'Botanizing rulers and their herbal subjects: plants and political power in Greek and Roman Literature', Phoenix 66, 122-43 
Van der Sanden, W., and Turner, R. 2004: ‘The Strata Florida manikin: how exotic is it?', Journal of Wetland Archaeology 4 (1), 83-96

Van der Veen, M. 1996: 'Plant remains', in Jackson and Potter1996, 613-39

Van der Veen, M. 2008: 'Food as embodied material culture: diversity and change in plant food consumption in Roman Britain', Journal of Roman Archaeology 21, 83-109

Van der Veen, M. 2011: Consumption, Trade and Innovation. Exploring the Botanical Remains from the Roman and Islamic Ports at Quseir al-Qadim, Egypt, Africa Magna, Frankfurt am Main

Van der Veen, M. 2014: 'The materiality of plants: plant-people entanglements', World Archaeology $46(5), 799-812$

Van der Veen, M., Livarda, A., and Hill, A. 2007: 'The archaeobotany of Roman Britain: current state and identification of research priorities', Britannia 38, 181-210

Van der Veen, M., Livarda, A., and Hill, A. 2008: 'New plant foods in Roman Britain - dispersal and social access', Environmental Archaeology 13 (1), 11-36

Versluys, M.J. 2014: 'Understanding objects in motion. An archaeological dialogue on Romanization', Archaeological Dialogues 21, 1-20

Waller, M.P., and Hamilton, S. 2000: 'Vegetation history of the English chalklands: a mid-Holocene pollen sequence from the Caburn, East Sussex', Journal of Quaternary Science 15, 253-72

Walters, H.B. 1899: Catalogue of the Bronzes, Greek, Roman, and Etruscan, in the Department of Greek and Roman Antiquities, British Museum, London

Walters, S., and Stow, E. 2001: Darwin's Mentor: John Stevens Henslow, 1796-1861, Cambridge

Wheeler, R.E.M., and Wheeler, T.V. 1936: Verulamium. A Belgic and Two Roman Cities, Society of Antiquaries Research Report 11, Oxford

Willcox, G. 1977: 'Exotic plants from Roman waterlogged sites in London', Journal of Archaeological Science 4 (3), 269-82

Willcox, G. 1980: 'The environmental evidence', in C. Hill, M. Millett and T. Blagg, The Roman Riverside Wall and Monumental Arch in London, London and Middlesex Archaeological Society Special Paper 3, London, 78-82

Wiltshire, P. 2000: 'The pollen assessment', in Anon. Report on the Excavations at the Zionshill Copse Enclosure, near Chandlers Ford, Hampshire, Berkshire Archaeological Services, 10-14 
Wiltshire, P. 2008: 'Palynological analysis of sediments from Roman waterholes', in P. Booth, A.M. Bingham and S. Lawrence, The Roman Roadside Settlement at Westhawk Farm Ashford, Kent, Excavations 1998-9, Oxford Archaeology Monograph 2, Oxford, 337-43

Witcher, R. 2013: 'On Rome's ecological contribution to British flora and fauna: landscape, legacy and identity', Landscape History 34 (2), 5-26

Zach, B. 2002: 'Vegetable offerings on the Roman sacrificial site in Mainz, Germany - short report on the first results', Vegetation History and Archaeobotany 11, 101-6

Zeepvat, R.J. 1991: 'Roman gardens in Britain', in Brown 1991, 53-9

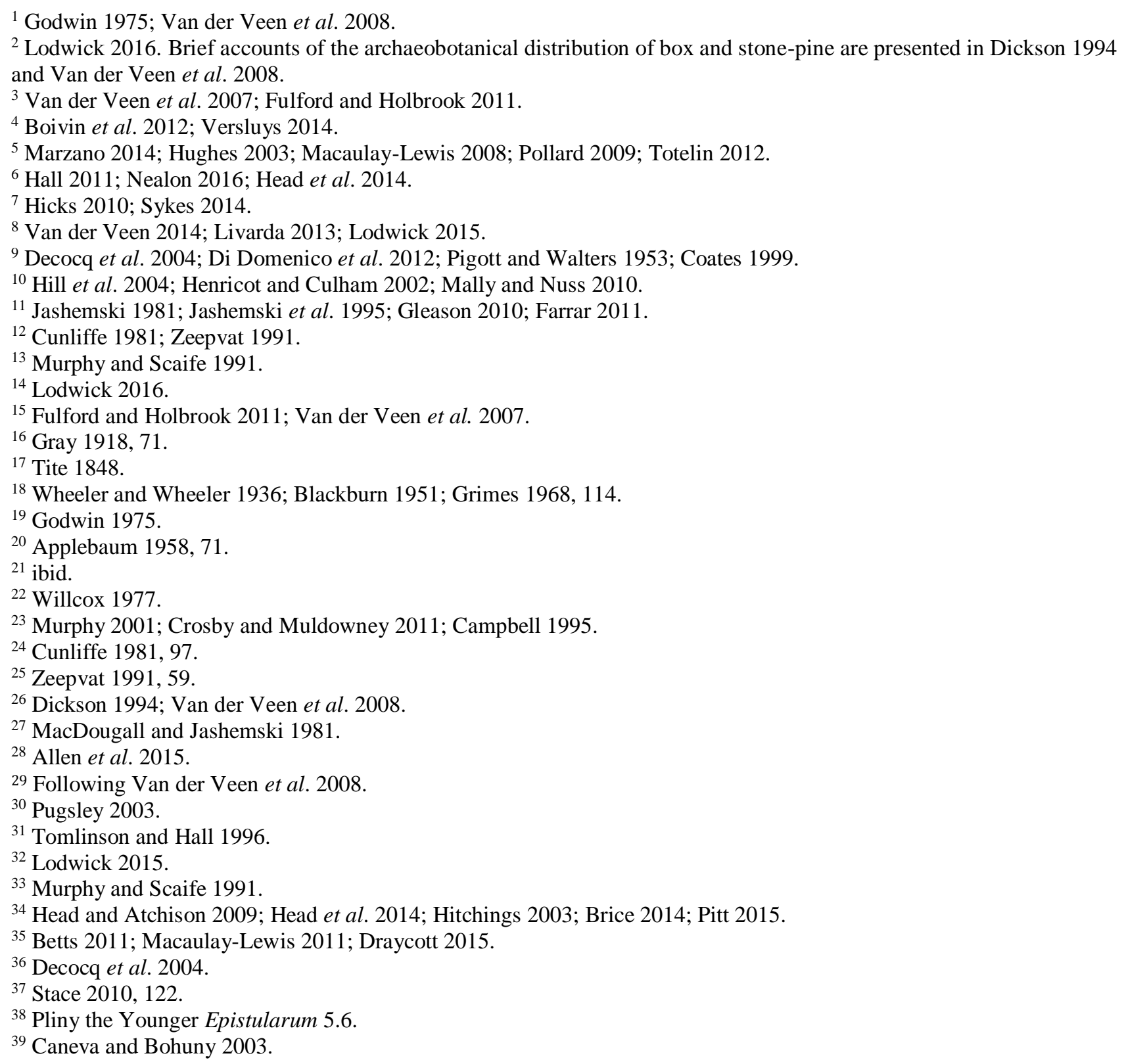


${ }^{40}$ Van der Veen 1996.

${ }^{41}$ Price 2000, 258; Challinor 2008.

42 Robinson 2015.

${ }^{43}$ Gage 1839; Eckardt et al. 2009.

${ }^{44}$ Fryer and Murphy 2014.

${ }^{45}$ Gray 1918.

${ }^{46}$ Allison 1947; Hood and Walton 1948.

${ }^{47}$ Draper's Garden: Unpublished environmental report: Batchelor et al. 2011; Preliminary publication: Butler and Ridgeway 2009

${ }^{48}$ Davenport et al. 2007, 33

${ }^{49}$ Van der Veen et al. 2008, 20

${ }^{50}$ Cunliffe 1981; Farrar 2011

${ }^{51}$ Meurers-Balke and Herchenbach 2014, fig. 4.

${ }^{52}$ Dimbleby 1978, 96.

${ }^{53}$ Hall et al 1980, 144.

${ }_{55}^{54}$ Fitter and Peat 1994.

${ }^{55}$ Mutke et al. 2012.

${ }^{56}$ Lodwick 2015.

${ }^{57}$ Caneva and Bohuny 2003.

${ }^{58}$ Mutke et al. 2012; Murphy et al. 2013.

${ }^{59}$ For instance, the Temple of Isis, Pompeii: Overbeck and Mau 1884, 108-109; Temple of Isis and Magna Mater, Mainz: Zach 2002; House of Amarantus, Pompeii: Robinson 2002; cremations in the Massif Central: Bouby and Marinval 2004; Northern Italy: Rottoli and Castiglioni 2011.

${ }^{60}$ Richmond and Gillam 1951; Kislev 1988. For review see Lodwick 2015.

${ }^{61}$ Van der Veen et al. 2008, 20.

${ }^{62}$ Lodwick 2015.

${ }^{63}$ Waterdale, Doncaster: Miller 2013. Mucking cemetery: Evans and Lucy 2008.

${ }^{64}$ Moser et al. 2012; Allevato et al. 2010; Caneva and Bohuny 2003; Giesecke and Bennett 2004.

${ }^{65}$ Murphy 2001, 17.

${ }^{66}$ Jackson and Potter 1996; Murphy 2001, 17.

${ }^{67}$ Davis 2011, 530

${ }^{68}$ Wiltshire 2008.

${ }^{69}$ Wiltshire 2000.

${ }^{70}$ Scaife 2011, 116.

${ }^{71}$ Rosati et al. 2015; Marzano 2014, 216-17; Gleason 1994; Pliny Nat. Hist. 12.6.

72 Taylor 1999, 17. Pit F75, Shire Hall Site. No details of sampling procedure, specialist, preservation, or quantified data are supplied. The pit was described as containing burnt material, suggesting a burnt offering may be the origin of this interesting assemblage.

${ }^{73}$ Barnett 2011.

${ }^{74}$ Van der Veen 2008, 102-4.

${ }^{75}$ Miller et al. 2016.

${ }^{76}$ Gray 1918; Fryer and Murphy 2014; Gage 1839.

${ }^{77}$ Farrar 2011, 135-8; Macaulay-Lewis 2008, 210; Kefalidou 2009, 40.

${ }^{78}$ Imported plant foods: Van der Veen et al. 2008. Wooden objects: Pugsley 2003. Boxwood transport: a shipwreck excavated at Commachio, dated to the late first century B.C., contained over 30 logs of long-growing Boxwood, Berti 1990, 53.

${ }^{79}$ Godwin 1975, 175; Mabey 1996, 254-6; Smith 2002, 31.

${ }^{80}$ Di Domenico et al. 2012.

${ }^{81}$ Bartley and Morgan 1990; Waller and Hamilton 2000; Oldfield and Statham 1963.

${ }^{82}$ Van der Sanden and Turner 2004.

${ }^{83}$ Coates 1999.

${ }^{84}$ Decocq et al. 2004.

${ }^{85}$ Giesecke and Bennett 2004; Tomlinson and Hall 1996.

${ }^{86}$ Mutke et al. 2012; Tomlinson and Hall 1996.

${ }^{87}$ Van der Veen 2011; Girard and Tchernia 1978.

${ }^{88}$ Murphy 1977, 85.

${ }^{89}$ Stevens 2011, 104.

${ }^{90}$ Columella, De Re Rustica 12. 30. 2; Lamboglia 1952, 146, 155-6.

${ }^{91}$ On stoppers from burials in Britain: Sealey 2009; Pliny Nat. Hist. 16.34.

${ }^{92}$ Bateman et al. 2008, 114; Goodburn 1999. 
${ }^{93}$ Busby et al. 2001, 111, 119.

${ }_{94}^{94}$ Bennett 1984.

${ }^{95}$ Campbell 1999; Pelling 2008, 357.

${ }^{96}$ Campbell 2008, 163.

${ }^{97}$ Alcock 1980, 54.

${ }^{98}$ RIB 75, RIB 612, 714; Blagg 2000, 62; Alcock 1980, 54.

${ }^{99}$ Dalton 1920, 58-60; Walters 1899, 32, entry 2579.

${ }^{100}$ For a summary see Crummy 2010, 63. Mithras: Bird 2004. Attis and Cybele: Green 1976, 212, 222; Tillyard 1917, Henig 1984. Sabazios: Eckardt 2014, 166. Sylvanus: Dorcey 1992, 17.

${ }^{101}$ Fless 1995, 111; Elsner 2012, 139; Robinson 2002, 97.

102 On literary mentions of Box: Pliny Nat. Hist. 16.18, 33, 17.35, Pliny the Younger Epistularum 5.6. For a review see Braimbridge 2008.

On the native status of box in Italy: Di Domenico et al. 2011. On discussions of botanical imperialism: Macaulay-Lewis 2008; Marzano 2014; Pollard 2009; Totelin 2012. On the association of boxwood with paleness: Pugsley 2003, 119.

${ }_{103}$ Mabey 1996, 256. France: Marinval et al. 2002 and references there in.

${ }^{104}$ Cunliffe 1981, 97; Zeepvat 1991, 59

${ }^{105}$ Brettell et al. 2015.

106 Sykes 2009.

107 Aldhouse-Green 2004; Chadwick 2015, 41; Pliny Nat. Hist. 16.95; Scaife 1986, 132.

${ }^{108}$ Gosden and Marshall 1999; Kopytoff 1986; Eckardt 2014.

${ }^{109}$ Draycott 2015; Betts 2011.

${ }^{110}$ Hall 2011; Daly et al. 2016; Thomas 2015, 1289.

${ }^{111}$ Van der Veen 2014; Sykes 2009, 30.

112 Jones and Cloke 2008, 80; Head et al. 2014, 864.

${ }^{113}$ Brice 2014; Pitt 2015; Head et al. 2014.

${ }^{114}$ Hitchings 2003.

${ }^{115}$ Pitt 2015.

${ }^{116}$ Bradley 2015a; Hamilakis 2011; Koloski-Ostrow 2015.

${ }^{117}$ Draycott 2015, 67.

${ }^{118}$ Pellegrini and Baudry 2014.

119 Temporality: Ingold 1993; Brice 2014; Draycott 2015. Appearance: Hitchings 2003; Pitt 2015.

Olafactory: Draycott 2015

${ }^{120}$ Mabey 1996, 254.

${ }^{121}$ Bernal et al. 2013.

122 Stace 2010, 122; Borchard et al. 2011.

${ }^{123}$ Ingold 1993, 168.

${ }^{124}$ Interpretation following Hill and Rowsome 2011, 433.

${ }^{125}$ Witcher 2013.

${ }^{126}$ Hamilakis 2011.

${ }^{127}$ Henshaw 2014, 42-56.

${ }^{128}$ Bennett 1984.

${ }^{129}$ Macchioni et al. 2003.

${ }^{130}$ Richmond and Gillam 1951.

${ }^{131}$ Monckton 2000.

${ }^{132}$ A review of macrofossil finds of Box in Europe can be found in Appendix tables S2 (pollen) and S3 (macrofossils) of

Di Domenico et al. 2012.

${ }^{133}$ Bosi et al. 2015.

${ }^{134}$ Mercuri et al. 2006.

${ }^{135}$ Marinval et al. 2002.

${ }^{136}$ Meurers-Balke and Herchenbach 2014 for an overview of mid-Rhine finds and Gaitzsch et al. 1989 for the full report of the Wiesweiler villa.

${ }^{137}$ Knörzer and Neu 1998 - reported as only the third find of box leaves from Germany.

${ }^{138}$ Bakels and Jacomet 2003.

139 Piranomonte 2015.

${ }^{140}$ Bulgaria: Popova 2010; Croatia: Šoštarić and Küster 2001; Israel: Ramsay 2010; Egypt: Van der Veen 2011.

${ }^{141}$ Peterken 2001. 